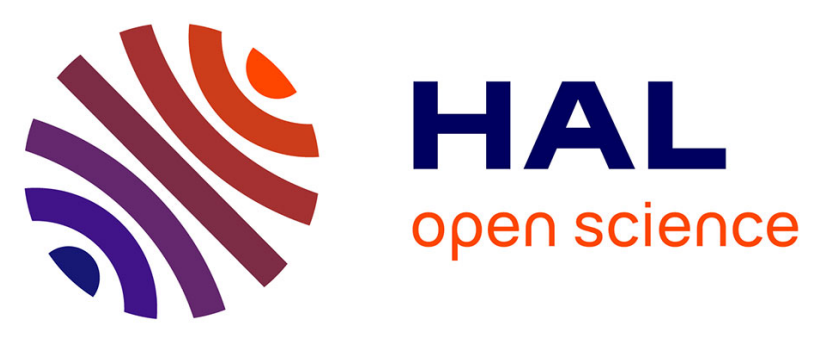

\title{
Impact of biotic and abiotic factors on the expression of fungal effector-encoding genes in axenic growth conditions
}

\author{
Michel Meyer, Ahmed Salim Bourras, Julie Gervais, Karine Labadie, Corinne \\ Cruaud, Marie-Helene Balesdent, Thierry Rouxel
}

\section{To cite this version:}

Michel Meyer, Ahmed Salim Bourras, Julie Gervais, Karine Labadie, Corinne Cruaud, et al.. Impact of biotic and abiotic factors on the expression of fungal effector-encoding genes in axenic growth conditions. Fungal Genetics and Biology, 2017, 99, pp.1 - 12. 10.1016/j.fgb.2016.12.008 . hal01608210

\section{HAL Id: hal-01608210 https://hal.science/hal-01608210}

Submitted on 25 May 2020

HAL is a multi-disciplinary open access archive for the deposit and dissemination of scientific research documents, whether they are published or not. The documents may come from teaching and research institutions in France or abroad, or from public or private research centers.
L'archive ouverte pluridisciplinaire HAL, est destinée au dépôt et à la diffusion de documents scientifiques de niveau recherche, publiés ou non, émanant des établissements d'enseignement et de recherche français ou étrangers, des laboratoires publics ou privés.

\section{(ㄷ)(1)(2)}

Distributed under a Creative Commons Attribution - ShareAlikel 4.0 International 
Regular Articles

\title{
Impact of biotic and abiotic factors on the expression of fungal effector-encoding genes in axenic growth conditions
}

\author{
Michel Meyer ${ }^{\mathrm{a}, *}$, Salim Bourras ${ }^{\mathrm{b}, \mathrm{c}}$, Julie Gervais ${ }^{\mathrm{a}}$, Karine Labadie ${ }^{\mathrm{d}}$, Corinne Cruaud ${ }^{\mathrm{d}}$, \\ Marie-Hélène Balesdent ${ }^{\mathrm{a}}$, Thierry Rouxel ${ }^{\mathrm{a}}$ \\ a UMR BIOGER, INRA, AgroParisTech, Université Paris-Saclay, 78850 Thiverval-Grignon, France \\ ${ }^{\mathrm{b}}$ Université Paris-Sud, 91400 Orsay, France \\ ' Institute of Plant Biology, University of Zürich, Zollikerstrasse 107, CH-8008 Zürich, Switzerland \\ ${ }^{\mathrm{d}}$ Centre National de Séquençage, CEA-Institut de Génomique, GENOSCOPE, 2 rue Gaston Crémieux, 91057 Evry Cedex, France
}

\section{A R T I C L E I N F O}

\section{Article history:}

Received 7 November 2016

Revised 15 December 2016

Accepted 22 December 2016

Available online 26 December 2016

\section{Keywords:}

Filamentous pathogenic fungus

Leptosphaeria maculans

Effector expression

Biotic and abiotic factors

Vegetative growth

\begin{abstract}
A B S T R A C T
In phytopathogenic fungi, the expression of hundreds of small secreted protein (SSP)-encoding genes is induced upon primary infection of plants while no or a low level of expression is observed during vegetative growth. In some species such as Leptosphaeria maculans, this coordinated in-planta upregulation of SSP-encoding genes expression relies on an epigenetic control but the signals triggering gene expression in-planta are unknown. In the present study, biotic and abiotic factors that may relieve suppression of SSP-encoding gene expression during axenic growth of $L$. maculans were investigated. Some abiotic factors (temperature, $\mathrm{pH}$ ) could have a limited effect on SSP gene expression. In contrast, two types of cellular stresses induced by antibiotics (cycloheximide, phleomycin) activated strongly the transcription of SSP genes. A transcriptomic analysis to cycloheximide exposure revealed that biological processes such as ribosome biosynthesis and rRNA processing were induced whereas important metabolic pathways such as glycogen and nitrogen metabolism, glycolysis and tricarboxylic acid cycle activity were downregulated. A quantitatively different expression of SSP-encoding genes compared to plant infection was also detected. Interestingly, the same physico-chemical parameters as those identified here for $L$. maculans effectors were identified to regulate positively or negatively the expression of bacterial effectors. This suggests that apoplastic phytopathogens may react to similar physiological parameters for regulation of their effector genes.
\end{abstract}

(c) 2017 Elsevier Inc. All rights reserved.

\section{Introduction}

Phytopathogenic fungi are responsible for huge crop losses worldwide. To infect successfully their host plant, fungi have developed diverse strategies to escape plant innate immunity and subvert host plant metabolism in order to enable the efficient uptake and utilization of host-derived nutrients. These strategies are based on the use of a cocktail of molecules named effectors that, in a broad sense, are defined as proteins and small molecules that can alter the structure and function of host cell (Hogenhout et al., 2009). Genome analyses of fungal phytopathogens have revealed that these pathogens have complex and diversified secretomes composed of hundreds of secreted proteins. Among them, several protein classes play important roles as effectors in pathogenicity [e.g. enzymes for secondary metabolite production,

\footnotetext{
* Corresponding author.

E-mail address: michel.meyer@inra.fr (M. Meyer).
}

phytotoxins, carbohydrate-active enzymes, peptidases, lipases, and small secreted proteins (SSPs)]. Large variations in the gene number of these different protein classes exist between the phytopathogenic fungi and could be correlated to the various pathogenic strategies adopted by fungi. For example, genomes of necrotrophs like Botrytis cinerea are enriched in genes encoding degrading enzymes such as protein and carbohydrate hydrolases along with non-ribosomal peptide synthetases (NRPSs) and polyketide synthases (PKSs) which encode enzymes involved in biosynthesis of secondary metabolites including non-specific metabolic toxins. In contrast, very few SSPs are produced, the main exception being cell-killing proteinaceous toxins (Amselem et al., 2011; Guyon et al., 2014). In biotrophs such as rust fungi, species differentiation towards pathogenicity has been accompanied by loss of numerous genes involved in nutrient acquisition, but expansion and diversification of effector genes encoding SSPs (Duplessis et al., 2011). For hemibiotrophs that display various modes of colonization of tissues including an early biotrophic stage 
at the beginning of infection, followed by a later necrotrophic stage, families of genes encoding peptidases, secondary metabolites enzymes, pectin-degrading enzymes and SSPs are expanded (Ohm et al., 2012). Genome-wide expression profiling has revealed that the expression of these pathogenicity genes is tightly regulated during infection. Different gene classes are coordinately transcribed in successive waves that are linked to pathogenic transitions of hemibiotrophs (O'Connell et al., 2012; Gervais et al., 2016).

Leptosphaeria maculans is a hemibiotroph with an unusually complex parasitic cycle tightly associated to that of its host plant Brassica napus (oilseed rape) (Rouxel and Balesdent, 2005). The fungus survives off season as a saprobe on stem residues of harvested plant. Sexual mating occurs at this stage resulting in the production of ascospores that are released and widely dispersed by wind. Ascopores germinate on leaf and host infection is initiated when growing hyphae penetrate inside the leaf via wounds and natural apertures such as stomata. At this stage, L. maculans colonizes the tissues as a biotroph, and grows exclusively within the apoplast. As it is the case for many other biotrophs or hemibiotrophs (Hacquard et al., 2012; Cantu et al., 2013; Dong et al., 2015; Mirzadi Gohari et al., 2015; Dobon et al., 2016), this initial step of tissue colonization is accompanied by a wave of concerted expression of effector genes encoding SSPs taking place before the fungus switches to necrotrophy (Rouxel et al., 2011).

The L. maculans genome has an unusual bipartite structure with guanine and cytosine (GC)-equilibrated regions alternating with adenine and thymine (AT)-rich isochores which contain mosaics of transposable elements (TE) mutated by repeat-induced point mutation process (Rouxel et al., 2011). Only 5\% of the genes are encountered in AT-rich isochores which cover $36 \%$ of the genome. Bioinformatic analysis of protein sequences has enabled to predict 651 SSPs in the secretome of this fungus. Twenty percent of the genes located in AT-isochores encode putative SSPs whereas $4.2 \%$ of the genes in the GC-isochores encode SSPs. In addition to SSPs, AT-isochores are also enriched in genes involved in response to chemical and biotic stimuli as well as PKSs and NRPSs. Similar features were found for other filamentous fungi with complex genomes in which specific compartments, usually TE-rich, are also enriched in genes involved in niche adaptation such as effectors (Spanu et al., 2010; Ma et al., 2010). This genome location has a major consequence on regulation of expression of effector genes. AT-isochores are heterochromatic and the gene location results in repression of the expression of effector genes located in ATisochores during vegetative growth of the fungus (Soyer et al., 2014). In contrast, during the first days of plant tissue colonization, microarray analyses indicated that $72.7 \%$ of the SSP-encoding genes located within AT-isochores (compared with 19.1-22.2\% in GC-isochores) are over-expressed compared to in vitro mycelium growth. The repression of expression of effector genes in axenic conditions seems to be a general trait in filamentous phytopathogens (Lo Presti et al., 2015), and there is currently no information on the environmental or plant-derived signals produced by leaves that could induce effector gene expression. During the systematic analysis of T-DNA tags in our collection of $5000 \mathrm{~L}$. maculans agrotransformants (Bourras et al., 2012), one T-DNA insertion was found in the promoter of a gene (hyp1) predicted to encode a hypothetical protein harboring a reverse transcriptase-like domain. Preliminary in vitro and in vivo analyses indicated that this integration event led not only to an overexpression of this gene but also to a deregulation of expression of genes encoding effectors like AvrLm4-7 and AvrLm6 (S. Bourras and M. Meyer, unpublished data). Recently, an orthologue of hyp1 present in Neurospora crassa was found to be strongly induced when protein synthesis was inhibited by the addition of antibiotics (cycloheximide, blasticidin) to the exponentially growing mycelium (Gladyshev and Arkhipova,
2011).This prompted us to investigate whether these antibiotics could also have an effect on the expression of $L$. maculans effectors. In addition, to propose a first evaluation of environmental signals that may be involved in derepression of expression of effector genes located within AT-isochores, we investigate here whether selected biotic and abiotic factors (including antibiotics) can influence the expression of $L$. maculans effector genes in axenic growth condition.

\section{Materials and methods}

\subsection{Reagents}

Cycloheximide, anisomycin, and puromycin were purchased from Sigma-Aldrich, Saint-Quentin Fallavier, France; hygromycin B was from Invitrogen, Cergy Pontoise, France; nourseothricin was from Werner BioAgents, Jena, Germany; blasticidin, phleomycin, and zeomycin were from Cayla, Toulouse, France.

\subsection{Fungal cultures and growth assays}

The general conditions used during our experiments were the following: $10^{8}$ conidia of the v23.1.3 isolate of $L$. maculans (Balesdent et al., 2002) were added to $50 \mathrm{ml}$ of minimal medium II (20 g of glucose, $2 \mathrm{~g}$ of $\mathrm{NaNO}_{3}, 0.1 \mathrm{~g} \mathrm{KH}_{2} \mathrm{PO}_{4}, 0.05 \mathrm{~g}$ of $\mathrm{MgSO}_{4}$, $0.05 \mathrm{~g} \mathrm{KCl}$, and $0.0001 \mathrm{~g}$ of $\mathrm{FeSO}_{4}, 7 \mathrm{H}_{2} \mathrm{O}$ per liter) or Fries medium (30 g of sucrose, $5 \mathrm{~g}$ of $\mathrm{C}_{4} \mathrm{H}_{12} \mathrm{~N}_{2} \mathrm{O}_{6}, 5 \mathrm{~g}$ of yeast extract, $1 \mathrm{~g}$ of $\mathrm{NH}_{4}$ $\mathrm{NO}_{3}, 1 \mathrm{~g} \mathrm{K \textrm {H } _ { 2 }} \mathrm{PO}_{4}, 0.13 \mathrm{~g}$ of $\mathrm{CaCl}_{2}, 0.1 \mathrm{~g} \mathrm{NaCl}$, and $0.05 \mathrm{~g} \mathrm{MgSO}_{4}$ per liter) in flasks incubated at $28{ }^{\circ} \mathrm{C}$ and shaked at $100 \mathrm{rpm}$. After 3 to 4 days of growth, the mycelium was harvested by filtration through sterile miracloth, dried, and immediately immersed in liquid nitrogen. When MMII medium was supplemented with different antibiotics at final concentrations of $0.1,1$ and $10 \mu \mathrm{g} /$ $\mathrm{ml}$, the culture was incubated for a further $3 \mathrm{~h}$. A time-course experiment was also performed by collecting fungal mycelium grown in MMII medium at 5, 10, 20, 30, 60, 120, 180 min after the addition of cycloheximide at $1 \mu \mathrm{g} / \mathrm{ml}$. Conidia were also grown in modified MMII medium (i) whose $\mathrm{pH}$ was adjusted at 5.0, 5.5, $6.0,6.5,7.0$ and 7.5 by the addition of $10 \mathrm{~N} \mathrm{NaOH}$; (ii) containing $\mathrm{NH}_{4}^{+}$at $1,5,20,50$ and $100 \mathrm{mM}$ as unique nitrogen source; (iii) containing glucose, fructose, sodium acetate, sodium succinate, sodium propionate and sodium citrate at $10 \mathrm{mM}$ as unique carbon source. For this later condition, the dry weight of mycelium collected was also measured. Finally, conidia were incubated in MMII medium at five different temperatures $\left(13^{\circ} \mathrm{C}, 16^{\circ} \mathrm{C}, 19^{\circ} \mathrm{C}, 22^{\circ} \mathrm{C}\right.$, $25^{\circ} \mathrm{C}$ ) but due to slower growth, mycelium was collected after 6 and 5 days of incubation at $13^{\circ} \mathrm{C}$ and $16{ }^{\circ} \mathrm{C}$, respectively.

On agar media, growth assays were performed by depositing $10 \mu \mathrm{l}$ of $10^{7} / \mathrm{ml}$ pynidiospores suspension at the center of $55 \mathrm{~mm}$-Petri dishes containing agar MMII medium. Antibiotics were added to solid MMII medium at final concentrations of 0.1 , 1 and $10 \mu \mathrm{g} / \mathrm{ml}$. Radial growth of $L$. maculans was measured after incubation at $25^{\circ} \mathrm{C}$ for two weeks.

\section{3. cDNA synthesis, PCR amplification, and real-time RT-PCR analysis}

Total RNA was extracted from freeze-dried mycelium by using TRIzol reagent (Invitrogen, Cergy Pontoise, France). Extracts were treated with DNAseI (Invitrogen, Cergy Pontoise, France) according to the manufacturer's instructions. Three micrograms of total RNA were reverse transcribed using an oligo-dT $\mathrm{T}_{(23)}$ anchor (SigmaAldrich, St. Louis) and 100 units of PowerScript Reverse Transcriptase (Ozyme, St-Germain-en-Laye, France) in a final volume of $20 \mu$ l. One microliter of RT reaction was used for PCR amplification in the final volume of $10 \mu \mathrm{l}$ using specific primer pairs (Supplemental Table S1). PCR conditions for AvrLm1, AvrLm4-7, AvrLm6, Lema086540 and Lemau086550 were as follows: 1 cycle 
at $95{ }^{\circ} \mathrm{C}$ for $5 \mathrm{~min}$, followed by 30 cycles at $95^{\circ} \mathrm{C}$ for $30 \mathrm{~s}, 56^{\circ} \mathrm{C}$ for $30 \mathrm{~s}$, and $72{ }^{\circ} \mathrm{C}$ for $45 \mathrm{~s}$, and a final extension step of $7 \mathrm{~min}$ at $72{ }^{\circ} \mathrm{C}$. PCR conditions for Lema103880 and Lema033060 were as follows: 1 cycle at $95^{\circ} \mathrm{C}$ for $5 \mathrm{~min}$, followed by 30 cycles at $95^{\circ} \mathrm{C}$ for $30 \mathrm{~s}$, $62{ }^{\circ} \mathrm{C}$ for $30 \mathrm{~s}$, and $72{ }^{\circ} \mathrm{C}$ for $30 \mathrm{~s}$, and a final extension step of 7 min at $72{ }^{\circ} \mathrm{C}$. PCR conditions for Lema070100 and Elongation Factor $1 \alpha$ were as follows: 1 cycle at $95^{\circ} \mathrm{C}$ for $5 \mathrm{~min}$, followed by 30 cycles at $95{ }^{\circ} \mathrm{C}$ for $30 \mathrm{~s}, 64^{\circ} \mathrm{C}$ for $30 \mathrm{~s}$, and $72{ }^{\circ} \mathrm{C}$ for $45 \mathrm{~s}$, and a final extension step of $7 \mathrm{~min}$ at $72{ }^{\circ} \mathrm{C}$.

Quantitative RT-PCR was performed as previously described (Fudal et al., 2007). The cDNA (75 ng) was amplified by real-time PCR using ABsolute SYBR Green Rox Mix (ABgene, Surrey, UK) in a 7900HT Fast Real-Time PCR System (Applied Biosystems) according to the manufacturer's instructions. The thermal cycling conditions were 1 cycle at $95^{\circ} \mathrm{C}$ for $15 \mathrm{~min}$, followed by 40 cycles at $95^{\circ} \mathrm{C}$ for $15 \mathrm{~s}$, and $60^{\circ} \mathrm{C}$ for $1 \mathrm{~min}$, and a final ramping step of $20 \mathrm{~min}$ from $60{ }^{\circ} \mathrm{C}$ to $95^{\circ} \mathrm{C}$. The primer pair used to detect cDNAs corresponding to actin was actF and actR (Supplemental Table S1). Similarly, oligonucleotides tubF/tubR, EF1 $\alpha Q \mathrm{QU} / \mathrm{EF} 1 \alpha \mathrm{QR}, \quad$ AvrLm1QU/ AvrLm1QL, AvrLm4-7QU/AvrLm4-7QL, and Lema086540QU/ Lema086540QL were used for $\beta$-tubulin, Elongation Factor $1 \alpha$ (EF1 $\alpha$ ), AvrLm1, AvrLm4-7, and Lema086540, respectively (Supplemental Table S1). Cycle threshold (Ct) values were analyzed according to the $2^{-\Delta \Delta \mathrm{Ct}}$ method (Livak and Schmittgen, 2001). $\beta$-tubulin or $E F 1 \alpha$ were used as a constitutive reference gene. Expression of actin relative to $\beta$-tubulin or $E F 1 \alpha$ was used as control.

\subsection{RNA sequencing and RNA-seq analysis}

Liquid MMII medium supplemented or not with cycloheximide was inoculated with $10^{8}$ conidia of the v23.1.2 isolate of $L$. maculans, a sister isolate of v23.1.3 (Balesdent et al., 2002) in which AvrLm1 is absent. For each condition, total RNAs from two biological replicates were extracted as described previously. The cDNA libraries and $100 \mathrm{bp}$ paired read sequencing were performed by the Genoscope (Evry, France) using Illumina HiSeq 2500 sequencer (Illumina, San Diego, CA, USA). Processing of raw Illumina sequence reads included the removal of adaptor sequences, and filtering and trimming for quality. All sequence shorter than 30 bases were discarded.

RNA-seq analysis was performed with the CLC Genomics Workbench v8.5.1 (Qiagen, Venlo, Netherlands) and all high-quality reads were mapped to the reference genome of v23.1.3 isolate of L. maculans (Rouxel et al., 2011). These data have been deposited in Gene Expression Omnibus database under accession number GSE89558. Gene expression was normalized and genes were considered differentially expressed if they possessed an absolute value of $\log _{2}$-fold change $\geqslant 2$ or $\leqslant 2$ and an adjusted $P$-value $\leqslant 0.01$ using the DESeq2 package (Love et al., 2014). Levels of gene expression were measured in fragments per kilo base of exon per million mapped reads (FPKM) (Trapnell et al., 2010) and a clustering, by average linkage, of fungal genes based on their expression was visualized in the form of a heat map using Gene Cluster 3.0 (de Hoon et al., 2004) and with Java Treeview (Saldanha, 2004). Gene ontology annotations were done with Blast2GO v3.0.9 and annotation enrichment analysis was performed with a Fisher exact test, using a False Discovery Rate (FDR) $\leqslant 0.05$ as a filter.

\section{Results}

3.1. Expression of candidate genes in rich and minimal culture media and effect of cycloheximide on the expression of genes encoding effectors

The v23.1.3 isolate was grown for three days in Fries complete medium or MMII minimal medium. The expression of nine genes was firstly evaluated by semiquantitative RT-PCR. These genes corresponded to three genes encoding effectors with an avirulence behavior (AvrLm1, AvrLm4-7, AvrLm6) (Fudal et al., 2007; Gout et al., 2006; Parlange et al., 2009) and five genes encoding SSPs which are effector candidates (Lema086540, Lemau086550, Lema103880, Lema033060, Lema070100). The three later genes encode orthologs of effectors identified in other fungal species: Lema_P103880 and Lema_P033060 are orthologs of the MGG_02154.6 protein, a biotrophy-associated secreted protein (BAS4) of Magnaporthe oryzae (Mosquera et al., 2009) (40\% identity, $53 \%$ similarity and 39\% identity, 50\% similarity, respectively). Lema_P070100 which contains five Lysin motifs is an ortholog of Ecp6 of Cladosporium fulvum (Bolton et al., 2008) (48\% identity, $67 \%$ similarity). Six of these genes (AvrLm1, AvrLm4-7, AvrLm6, Lema086540, Lemau086550, Lema033060) are located in ATisochores whereas the two others (Lema103880, Lema070100) are located in GC-isochores. Elongation Factor $1 \alpha(E F 1 \alpha)$, a housekeeping gene, was included as a control. Amplification products of the expected size were obtained from genomic DNA for all genes except Lema070100 for which an additional slightly higher-sized band was amplified (Fig. 1). Following semiquantitative RT-PCR in the Fries complete and MMII minimal media, a PCR product of high intensity was obtained for EF1 $\alpha$ whereas no or low intensity amplification product was detected for five of the effector genes located in AT-isochores. In contrast, a PCR product was detected for Lema033060 in MMII medium only, and for the two genes located in GC-isochores, either in Fries medium (Lema103880) or in MMII medium (Lema070100) (Fig. 1). This confirms previous expression analyses which have shown that most SSP-encoding genes located in AT-rich isochores are expressed at low levels or not detectable during vegetative growth (Parlange et al., 2009; Ghanbarnia et al., 2014) while this is not the case for SSPencoding genes in GC-isochores.

The influence of cycloheximide on the expression of effector genes was then evaluated. Following three days of growth in liquid media, cycloheximide was added and germinated conidia of the v23.1.3 isolate were grown a further $3 \mathrm{~h}$ before RNA extraction. For $E F 1 \alpha$, amplification products of equal intensity were detected whatever the growth medium and the antibiotic concentrations used. The expression of Lema070100 was unchanged in the presence of the antibiotic while all other genes showed increased expression in one condition or the other when cycloheximide was added to the medium (Fig. 1). In Fries medium, the level of expression highly increased for three of the genes located in ATisochores (Lema086540, Lemau086550, Lema033060) and the highest intensity bands were obtained at the lowest concentration of cycloheximide used $(0.1 \mu \mathrm{g} / \mathrm{ml})$ (Fig. 1). Lema033060, however, did not react to the addition of cycloheximide in MMII medium. With the main exception of the latter gene, the five other SSPencoding genes located in AT isochores were strongly overexpressed in the presence of cycloheximide at $1 \mu \mathrm{g} / \mathrm{ml}$ in MMII medium, some of them showing a limited increased expression at concentrations as low as $0.1 \mu \mathrm{g} / \mathrm{ml}$ (AvrLm1, AvrLm4-7, Lemau086550) (Fig. 1). Lema103880 located in GC-isochore also showed an induced expression in the presence of 1 and $10 \mu \mathrm{g} / \mathrm{ml}$ of cycloheximide in MMII. These data showed that the addition of cycloheximide to minimal medium was conducive to increased expression of effector genes, and further studies to investigate factors that may induce expression of effector genes in vitro were done in MMII medium with a choice of three out of the five genes showing the same expression profile used as template: Avrlm1, AvrLm4-7 and Lema086540.

Quantitative RT-PCR analyses confirmed the data obtained with RT-PCR and showed similar dose-response patterns of expression in the presence of cycloheximide for the three genes: their transcript levels increased with $0.1 \mu \mathrm{g} / \mathrm{ml}$ cycloheximide 


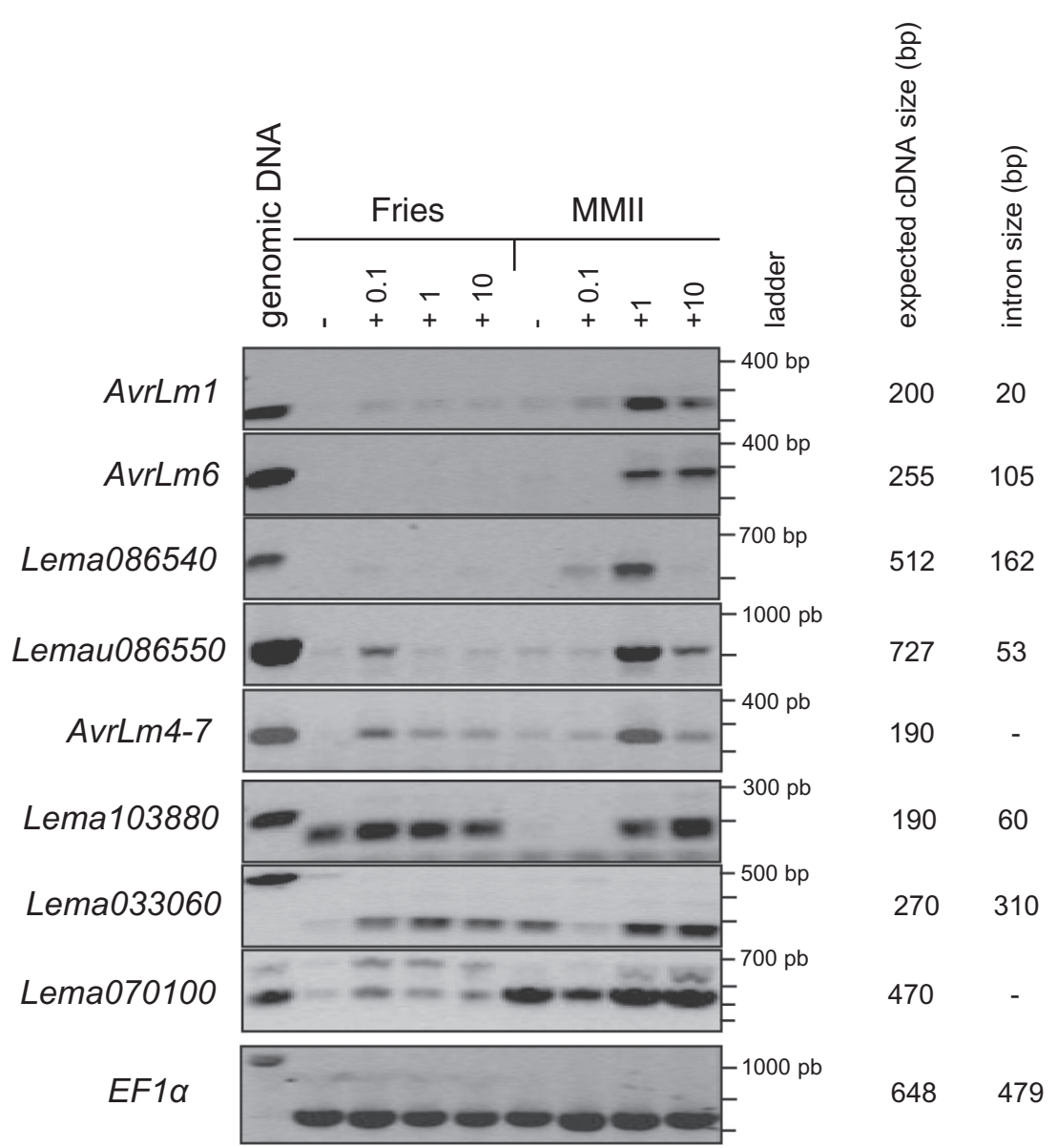

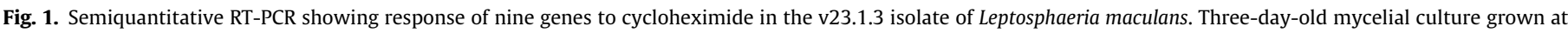

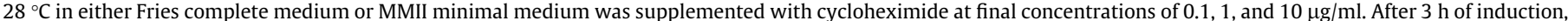

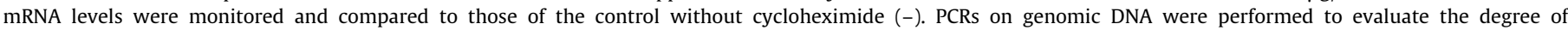

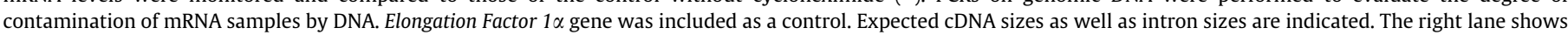
the position of DNA bands of GeneRuler $1 \mathrm{~kb}$ DNA Ladder (Thermo Scientific).

(4.4-, 7.5-, 3.7-fold vs. control), peaked with $1 \mu \mathrm{g} / \mathrm{ml}$ cycloheximide (21.3-, 59.0-, 23.6-fold vs. control) and then decreased with $10 \mu \mathrm{g} / \mathrm{ml}$ cycloheximide (4.0-, 24.0-, 4.4-fold vs.control) (Fig. 2A).

We next investigated the minimum exposure time of fungal conidia to cycloheximide needed to induce a strong increase of expression of AvrLm1, AvrLm4-7 and Lema086540. Three day old germinating conidia were incubated with cycloheximide at $1 \mu \mathrm{g} /$ $\mathrm{ml}$ for different period of time ranging from $5 \mathrm{~min}$ to $3 \mathrm{~h}$. As shown in Fig. 2B, the expression profiles of the three genes were again very similar. A slight increase in transcript levels was seen 10 min after the addition of cycloheximide to the culture medium (3.2-, 2.8-, 2.2-fold vs control) and the peak of expression was detected after exposing conidia to cycloheximide for 2 or $3 \mathrm{~h}$ (17.6-, 77.5-, 40.5-fold vs control) (Fig. 2B).

\subsection{Antibiotics belonging to the aminoglycoside class impact fungal growth}

The effect of six antibiotics affecting protein synthesis by different mechanisms was evaluated at concentrations of $0.1,1$ and $10 \mu \mathrm{g} / \mathrm{ml}$. All these six antibiotics belong to the aminoglycoside class. Compared to the aerial whitish mycelium observed on agar MMII medium without antibiotic, the morphology of the fungus was always altered in the presence of antibiotic, its mycelium looking more compact and whiter (Supplemental Fig. S1A). Cyclohex- imide, which inhibits the eukaryotic translation machinery by blocking the translocation step (Schneider-Poetsch et al., 2010), had the strongest impact on L. maculans growth and strongly inhibited fungal growth after 14 days of growth at concentration as low as $0.1 \mu \mathrm{g} / \mathrm{ml}$ (Supplemental Fig. S1A). In contrast, hygromycin B and anisomycin only had a limited impact on L. maculans growth even at the highest concentration tested (Supplemental Fig. S1A). The three other antibiotics had a severe effect on $L$. maculans growth for the higher concentration used only $(10 \mu \mathrm{g} / \mathrm{ml}$ ) (Supplemental Fig. S1A).

3.3. Other aminoglycosides influence the expression of genes encoding effectors regardless of their effect on fungal growth

In term of effector gene expression, results similar to those obtained with cycloheximide were obtained with blasticidin and anisomycin, while one of these antibiotics had no effect on fungal growth and the other only had an effect at the highest concentration analyzed (data not shown). In both cases, the concentration of antibiotic inducing the highest levels of transcripts was $1 \mu \mathrm{g} / \mathrm{ml}$ (Supplemental Fig. S2). However, smaller increases of transcript levels were measured with both antibiotics: 6.5-, 15.3-fold vs control (for Avrlm1 and AvrLm4-7) with blasticidin; 4.0-, 7.0-, 3.8-fold vs control with anisomycin, compared to the effect of cycloheximide. In contrast, whatever the concentration of antibiotic used, 


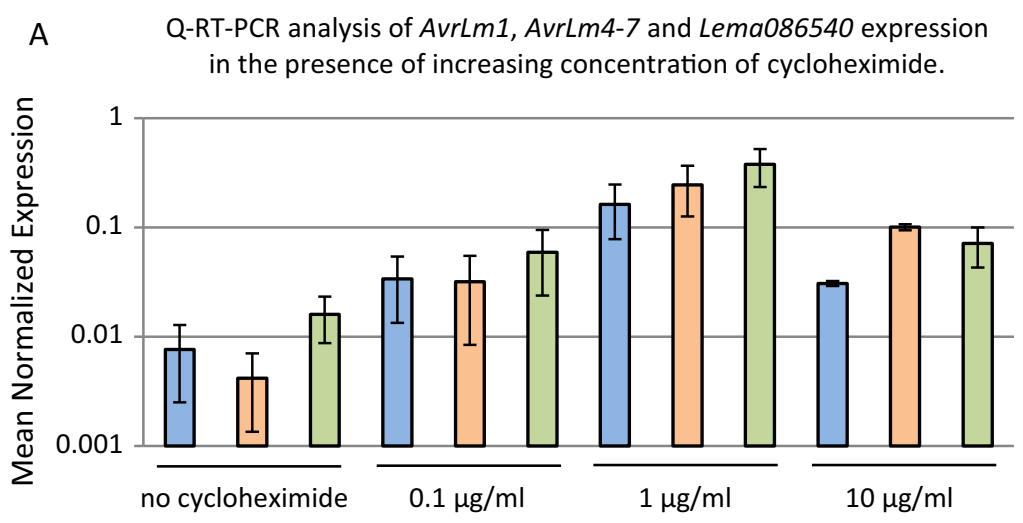

B

Q-RT-PCR analysis of AvrLm1, AvrLm4-7 and Lema086540 expression after exposure of L. maculans to cycloheximide $(1 \mu \mathrm{g} / \mathrm{ml})$ for 5 to $180 \mathrm{~min}$.

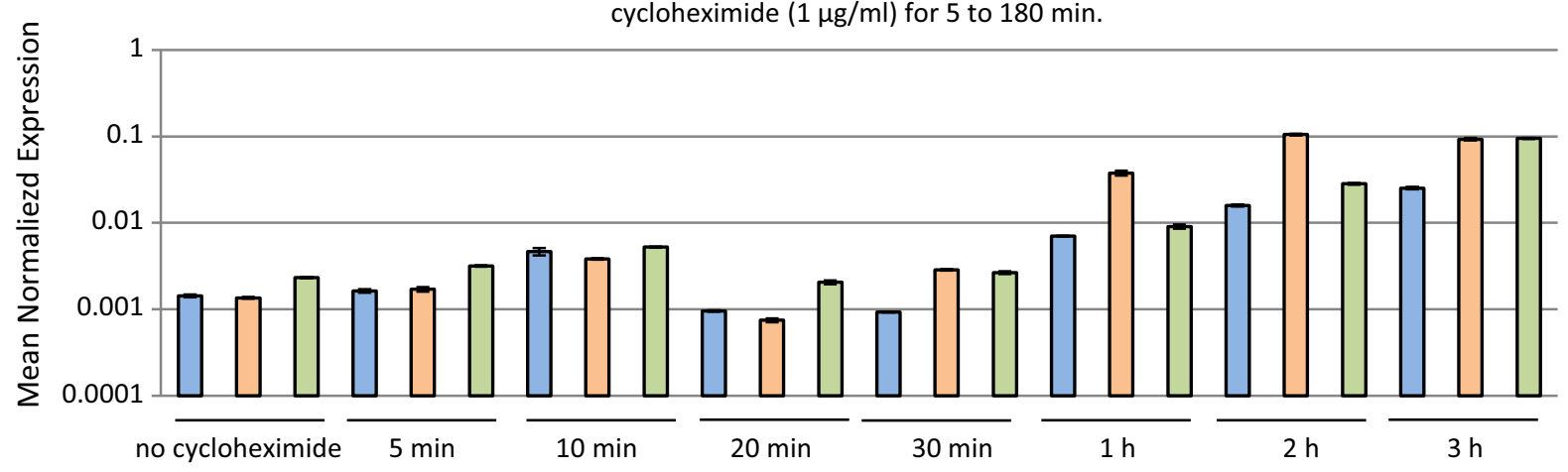

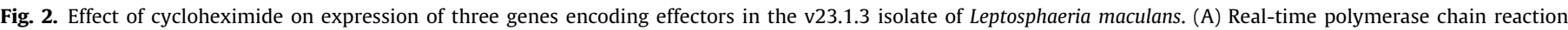

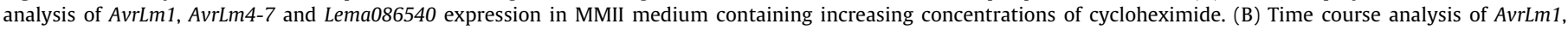

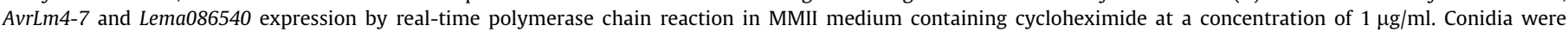

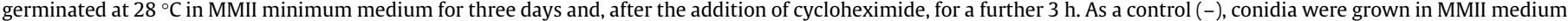

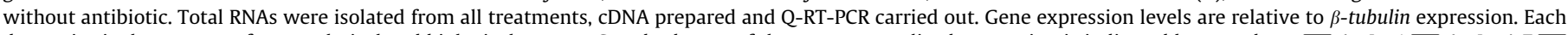

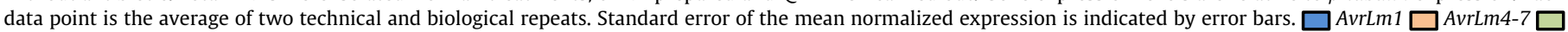
Lema086540.

no effect of puromycin, hygromycin B and nourseothricin could be observed on regulation of the expression of the three genes (Supplemental Fig. S2).

\subsection{Antibiotics of the bleomycin family point to an effect of $\mathrm{pH}$ on growth and regulation of expression of effector genes}

We further investigated the ability of L. maculans to respond to antibiotics with a distinct mode of action to that of aminoglycosides. Phleomycin belongs to the family of bleomycin antibiotics which bind and intercalate DNA thus eliciting double-strand DNA breaks (DSBs) (Suzuki et al., 1970). As the sensitivity of eukaryotic microorganisms to phleomycin is $\mathrm{pH}$ dependent with greater sensitivity at higher $\mathrm{pH}$, the $\mathrm{pH}$ of the liquid MMII medium was adjusted at 7.5 (usual $\mathrm{pH}$ of the MMII medium is 4.6). This $\mathrm{pH}$, however, strongly impacted fungal growth (Supplemental Fig. S1B). Regardless of the effect of pH per se on fungal growth, phleomycin induced morphological changes of mycelium similar to those observed with aminoglycosides and had a strong effect on radial growth departing from $1 \mu \mathrm{g} / \mathrm{ml}$ of phleomycin (Supplemental Fig. S1B). Comparison of AvrLm1, AvrLm4-7 and Lema086540 transcript levels between conidia grown in MMII medium at $\mathrm{pH} 4.6$ and 7.5 also showed that an increase of the medium $\mathrm{pH}$ induced a ca. 7.0-fold decrease in transcript level of the three genes concomitantly with growth reduction (Fig. 3). The addition of phleomycin to the medium had a strong effect on increase of transcript level whatever the $\mathrm{pH}$ of the medium. The higher concentration induced the strongest overexpression for
AvrLm1, AvrLm4-7 and this effect was more marked at a basic than at an acidic pH (29.2-, 19.1-fold vs control at pH 4.6 and 42.9-, 35.4 -fold vs control at $\mathrm{pH} 7.5$ for $3 \mathrm{~h}$ exposure to $10 \mu \mathrm{g} / \mathrm{ml}$ phleomycin, respectively) (Fig. 3). The effect was less important for Lema086540 with no increase with increasing concentrations of antibiotics (Fig. 3).

\subsection{RNA-seq-based transcriptome analysis of Leptosphaeria maculans} in response to exposure to cycloheximide

To identify the changes occurring in the L. maculans transcriptome after exposure to cycloheximide, high-throughput RNAseq data obtained with a sister isolate (v23.1.2) of v23.1.3 isolate were analyzed. To validate these RNAseq data, the cycloheximide effect on growth and effector gene expression of v23.1.2 was firstly evaluated. The growth inhibition pattern observed for v23.1.2 was identical to that previously reported for v23.1.3 with a severe growth defect at $0.1 \mu \mathrm{g} / \mathrm{ml}$ of cycloheximide and virtually no fungal growth at $1 \mu \mathrm{g} / \mathrm{ml}$ of cycloheximide (Supplemental Fig. S3A). As Avrlm1 is absent in v23.1.2, effector gene expression was performed on AvrLm4-7 and Lema086540. Again, as previously reported for v23.1.3, a peak of expression was obtained for these two genes at $1 \mu \mathrm{g} / \mathrm{ml}$ of cycloheximide (784.3- and 109.7-fold vs control) (Supplemental Fig. S3B). From these controls which revealed no difference between v23.1.2 and v23.1.3 exposed to cycloheximide, we assume that the transcriptional changes observed with v23.1.2 will reflect those of v23.1.3. A total of 
Q-RT-PCR analysis of AvrLm1, AvrLm4-7 and Lema086540 expression at different pH in the presence of increasing concentration of phleomycin

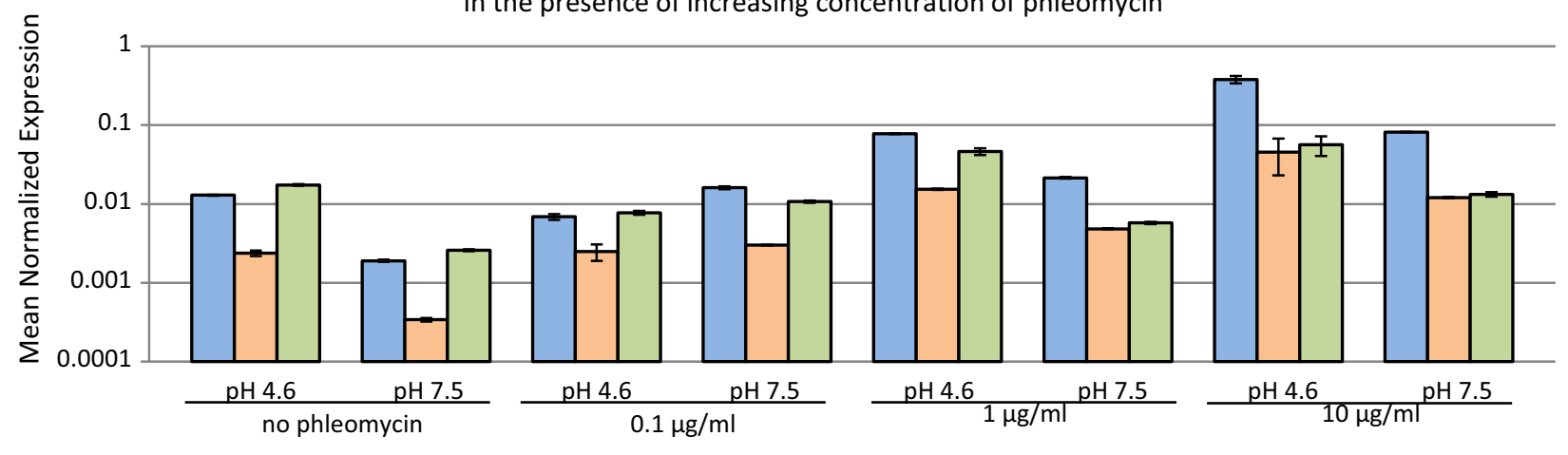

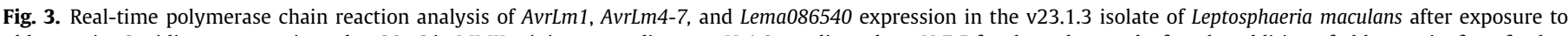

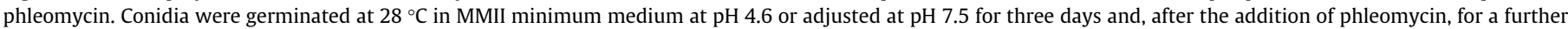

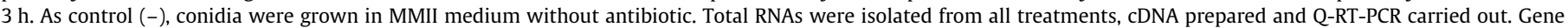

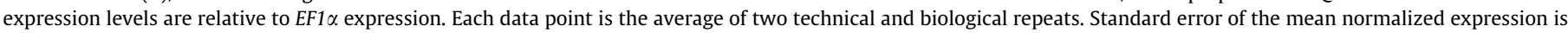
indicated by error bars. $\square$ AvrLm1 $\square$ AvrLm4-7 $\square$ Lema086540.

180521592 high quality reads was generated corresponding to 41.1 to 51.2 million reads depending on the sample (Table 1 ). Of the mapped reads ( $85 \%$ to $88 \%$ of the reads), $99.9 \%$ had unique match in the genome. On average, $86.1 \%$ and $82.8 \%$ of expressed genes were identified as being expressed for the samples without and with cycloheximide, respectively (Table 1). Gene expression levels were analyzed in a pairwise comparison using the $\log _{2^{-}}$ normalized gene expression and an adjusted $P$-value $\leqslant 0.05$. These transcriptional changes visualized via a heat map indicated that 6 603 genes were modulated in response to cycloheximide with a nearly equal number of genes up- or down-regulated ( 3301 versus 3302 genes, respectively) in the presence of cycloheximide (Fig. 4A). With a cut-off threshold of -2.0 and $2.0 \log _{2}$-fold changes in gene expression and a stringent adjusted $P$-value $\leqslant 0.01$, two subsets of 861 up-regulated and 888 down-regulated genes were obtained. The expression of 109 genes encoding SSPs $(16.7 \%$ of the genes encoding SSPs in the genome) was affected by the cycloheximide treatment which is comparable to the $14 \%$ of genes of the genome affected by the antibiotic treatment. Within the upregulated genes, 53 corresponded to SSP-encoding genes with $15.1 \%$ of these genes located in AT-isochores, and thus no specific enrichment in genes as a function of their genome location was observed. These nevertheless include genes of known incidence in fungal pathogenicity such as the four cloned avirulence genes AvrLm3, AvrLm4-7, AvrLmJ1 and AvrLm11 along with LmCys2, encoding an effector known to suppress the plant defence response (Rouxel et al., 2011; Gout et al., 2006; Balesdent et al., 2013; Van de Wouw et al., 2014; Plissonneau et al., 2016) (Supplemental Table S2). Despite its up-regulation in our in vitro experiment, Lema086540 was not retained as its $\log _{2}$-fold change was of only 1.8 and thus below our threshold. Two other genes (Lema006106,
Lema084480), recently found to encode for SSP required for full or partial suppression of cell death (Haddadi et al., 2016) and located in GC-isochores were also up-regulated in presence of cycloheximide (Supplemental Table S2). In contrast, other avirulence genes located in AT-isochores such as AvrLm6 and AvrLm2 were not significantly affected by the cycloheximide treatment (data not shown). Another gene (Lema_uP002480) encoded a predicted protein with homology to the processed domain of the plant regulatory peptide RALF (rapid alkalinization factor). Plant RALF homologues have been detected in Dothideomycetes, Sordariomycetes and Pucciniomycetes and RALF knockout mutants have been shown to reduce the virulence of Fusarium oxysporum in tomato plants (Masachis et al., 2016). A BLASTp analysis showed that 3 SSP-encoding genes were affected (Lema049970, Lema036180, Lema067060) of which the protein product had Pfam domains corresponding to hydrolytic enzymes (a $\beta$ 1-3 glucosidase, a glycoside hydrolase and a glucanase) (Supplemental Table S2). Fifty-six SSP-encoding genes, of which $94.7 \%$ were located in GC-isochores, were found to be down-regulated in the presence of cycloheximide (Supplemental Table S3). Of these, the sp1 gene (Lema105100) encodes a protein showing high similarity to SSPs from other ascomycetes but a null mutant has no effect on pathogenicity of L. maculans on B. napus (Wilson et al., 2002). Six other down-regulated genes (Lema020160, Lema099100, Lema102730, Lema029900, Lema108620) encoded SSPs predicted to have a hydrolytic enzyme domain corresponding to a carboxypeptidase, a pectate lyase, a hydrolase, a glucanase and a ribonuclease, respectively (Supplemental Table S3). The remainder (Lema008870) encoded a metalloprotease which has previously been identified as a member of a broadly conserved effector family and a powdery mildew ortholog has been shown to suppress host

Table 1

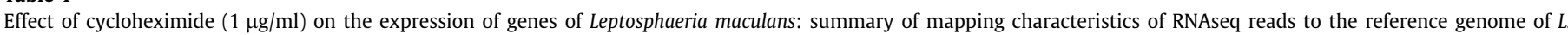
maculans.

\begin{tabular}{|c|c|c|c|c|c|c|}
\hline Condition & Replicate $\mathrm{n}^{\circ}$ & Total number of reads & $\begin{array}{l}\text { Reads mapped to the } \\
\text { L maculans genome }\end{array}$ & $\%$ & $\begin{array}{l}\text { Number of } L . \text { maculans } \\
\text { expressed genes }\end{array}$ & $\% \mathrm{c}$ \\
\hline Mycelium & 1 & $41,124,980$ & $33,034,858$ & 80.33 & 10,836 & 85.45 \\
\hline Mycelium & 2 & $45,658,422$ & $41,212,582$ & 90.26 & 11,017 & 86.87 \\
\hline Average & & & & 85.29 & 10,926 & 86.16 \\
\hline Cycloheximide & 1 & $42,526,082$ & $36,395,040$ & 85.58 & 10,342 & 81.55 \\
\hline Cycloheximide & 2 & $51,212,108$ & $46,572,670$ & 90.94 & 10,681 & 84.22 \\
\hline Average & & & & 88.26 & 10,511 & 82.88 \\
\hline
\end{tabular}

\footnotetext{
a Only reads mapped in pairs were counted.

b $\geqslant 10$ reads.

c Compared to the 12,681 genes predicted in Leptosphaeria maculans genome (Rouxel et al., 2011).
} 
A
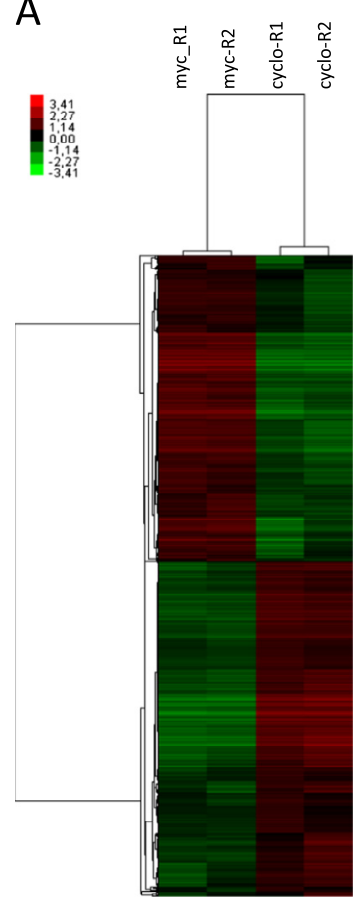

B
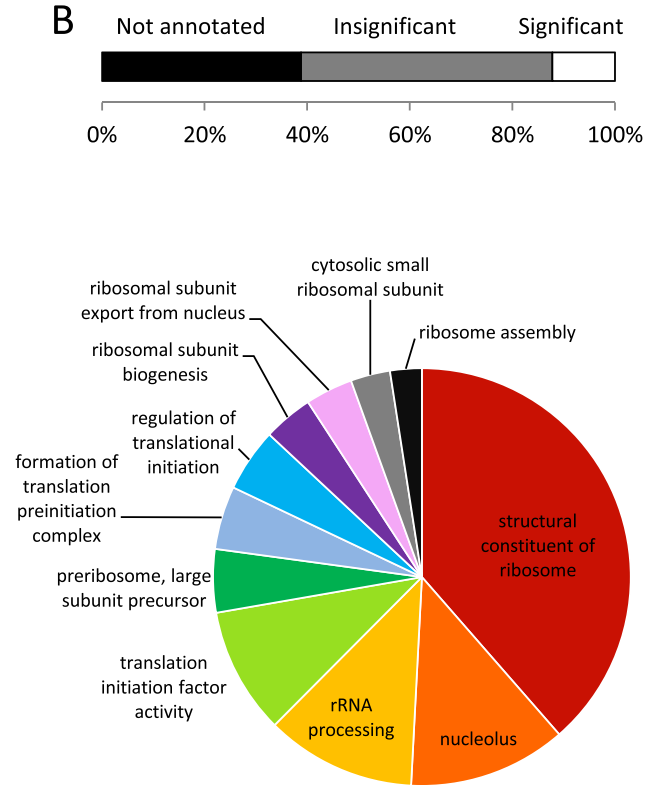

C
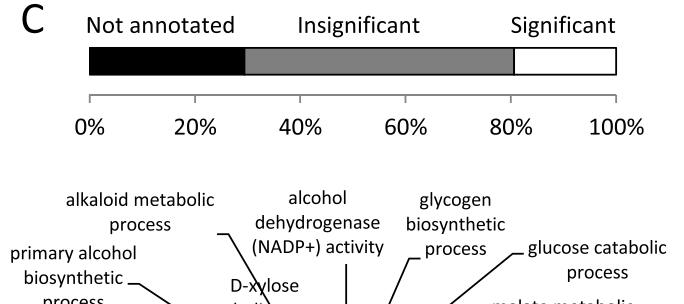

process metabolicprocess malate metabolic

nitrogen cycle

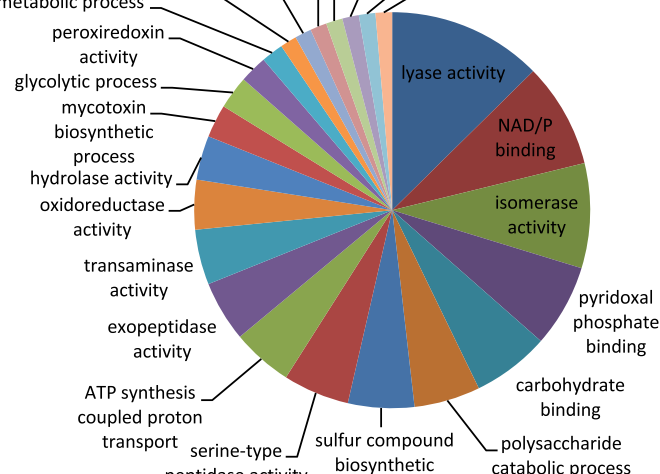

$\begin{array}{cc}\text { peptidase activity } & \begin{array}{c}\text { biosynthetic } \\ \text { process }\end{array}\end{array}$

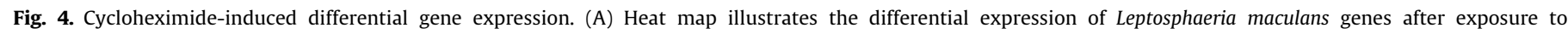

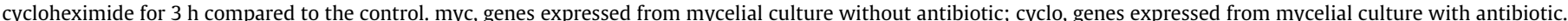

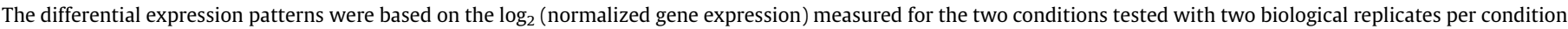

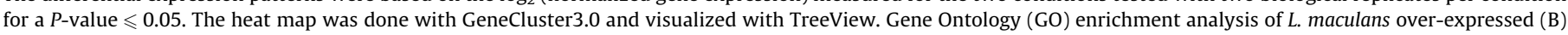

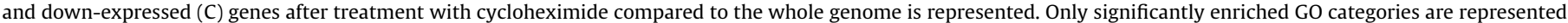
$($ FDR $\leqslant 005)$. This analysis was performed with Blast2GO.

cell death and to contribute to Blumeria graminis virulence on barley (Whigham et al., 2015).

For the remaining genes, only $12 \%$ and $19 \%$ of the up- and down-regulated genes, respectively, had a predicted GO with significant enrichment (FDR $\leqslant 0.05$ ) compared to the whole genome (Fig. 4). In the subset of up-regulated genes, the biological processes were enriched in ribosome biosynthesis with genes encoding ribosomal proteins and required for ribosome biogenesis as well as rRNA processing and in translational initiation with genes encoding eukaryotic translation initiation factor subunits (Fig. 4B). In agreement with this biological classification, the cellular localization category was enriched in GO term related to nucleolus, the largest structure in the nucleus of eukaryotic cells where it serves as the site of ribosome synthesis and assembly. In the sub- set of down-regulated genes, numerous biological processes were impacted including notably the synthesis and the degradation of carbon sources, the use of nitrogen sources, key biochemical cycles providing energy and essential constituents such as amino acids and nucleotides to the cell, oxidoreductase and hydrolase activities, the biosynthesis of secondary metabolites involved in cell protection and defence responses to oxidative stress (Fig. 4C).

\subsection{Comparison of expression patterns of SSP-encoding genes differentially expressed after exposure to cycloheximide or during plant infection}

The expression pattern of the 109 SSP-encoding genes differentially expressed in response to cycloheximide treatment was

Table 2

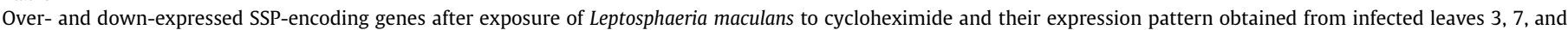
14 days post-inoculation.

\begin{tabular}{|c|c|c|c|c|c|c|c|c|c|}
\hline \multirow[t]{3}{*}{ Genomic location $^{\mathrm{a}}$} & \multirow[t]{3}{*}{ Total $n^{\circ}$ of genes } & \multicolumn{8}{|c|}{ Expression data during early stages of infection of cotyledons ${ }^{b}$} \\
\hline & & \multicolumn{3}{|c|}{ Overexpressed } & \multicolumn{3}{|c|}{ Repressed } & \multirow[t]{2}{*}{$\# \mathrm{~N} / \mathrm{A}^{\mathrm{d}}$} & \multirow[t]{2}{*}{ Data missing } \\
\hline & & $3 \mathrm{dpi}^{\mathrm{c}}$ & 7 dpi & $14 \mathrm{dpi}$ & 3 dpi & 7 dpi & $14 \mathrm{dpi}$ & & \\
\hline \multicolumn{10}{|c|}{ Over-expressed SSP-encoding genese $e^{\mathrm{e}}$} \\
\hline AT-isochores & 8 & & 7 & & & & & & 1 \\
\hline GC/AT-isochores & 6 & & & & & 1 & & 4 & 1 \\
\hline GC-isochores & 39 & 4 & 10 & 2 & & & & 22 & 1 \\
\hline \multicolumn{10}{|c|}{ Down-expressed SSP-encoding genes ${ }^{\mathrm{e}}$} \\
\hline AT-isochores & 1 & & 1 & & & & & & \\
\hline GC/AT-isochores & 2 & 1 & & & & & & 1 & \\
\hline GC-isochores & 53 & 7 & 4 & 4 & 3 & & 1 & 34 & \\
\hline
\end{tabular}

a AT-isochores: genomic blocks with low GC content; GC/AT-isochores: transition regions ( $859 \pm 385$ bp) between AT-blocks and GC-blocks; GC-isochores: genomic blocks with equilibrated GC content (Rouxel et al., 2011).

b Data retrieved from the L. maculans whole-genome expression array (Rouxel et al., 2011).

c dpi: day post-inoculation.

d N/A: not available.

e Genes with a $\log _{2}$-fold change $\geqslant 2$ and a false discovery rate $\leqslant 0.05$ were considered. 
compared to previously obtained microarray data of plant infected by v23.1.3 (Rouxel et al., 2011). No expression in-planta was detected for $54.7 \%$ and $62.5 \%$ SSP-encoding genes up- and down-regulated, respectively, following cycloheximide exposure (Table 2 ). With the main exception of one gene located in border GC/AT-isochore, all the remaining SSP-encoding genes over-expressed in vitro in response to cycloheximide were also over-expressed in-planta. This included seven genes located in an AT-rich environment as well as sixteen genes located in GC-isochores, $62.5 \%$ of them showing a peak of expression at 7 days post-inoculation (Table 2). Only $19 \%$ of the SSP-encoding genes whose expression was repressed in response to cycloheximide treatment were found to be also repressed in- planta. All of them corresponded to genes located within GCisochores (Table 2). This comparison indicated that there is only a limited overlap between these two patterns of gene expression. The coordinated upregulation of effectors genes expression (including AvrLm1, AvrLm4-7, and Lema086540) has been shown previously to depend on an epigenetic control mediated by the heterochromatin protein 1 (HP1) and the histone methyltransferase (DIM-5) (Soyer et al., 2014). However, no significant variation of the HP1 and Dim-5 expression level was detected in vitro following the treatment with cycloheximide. Thus, the mechanism involved in the deregulation of effector expression during the exposure of $L$. maculans to cycloheximide remains to be determined.
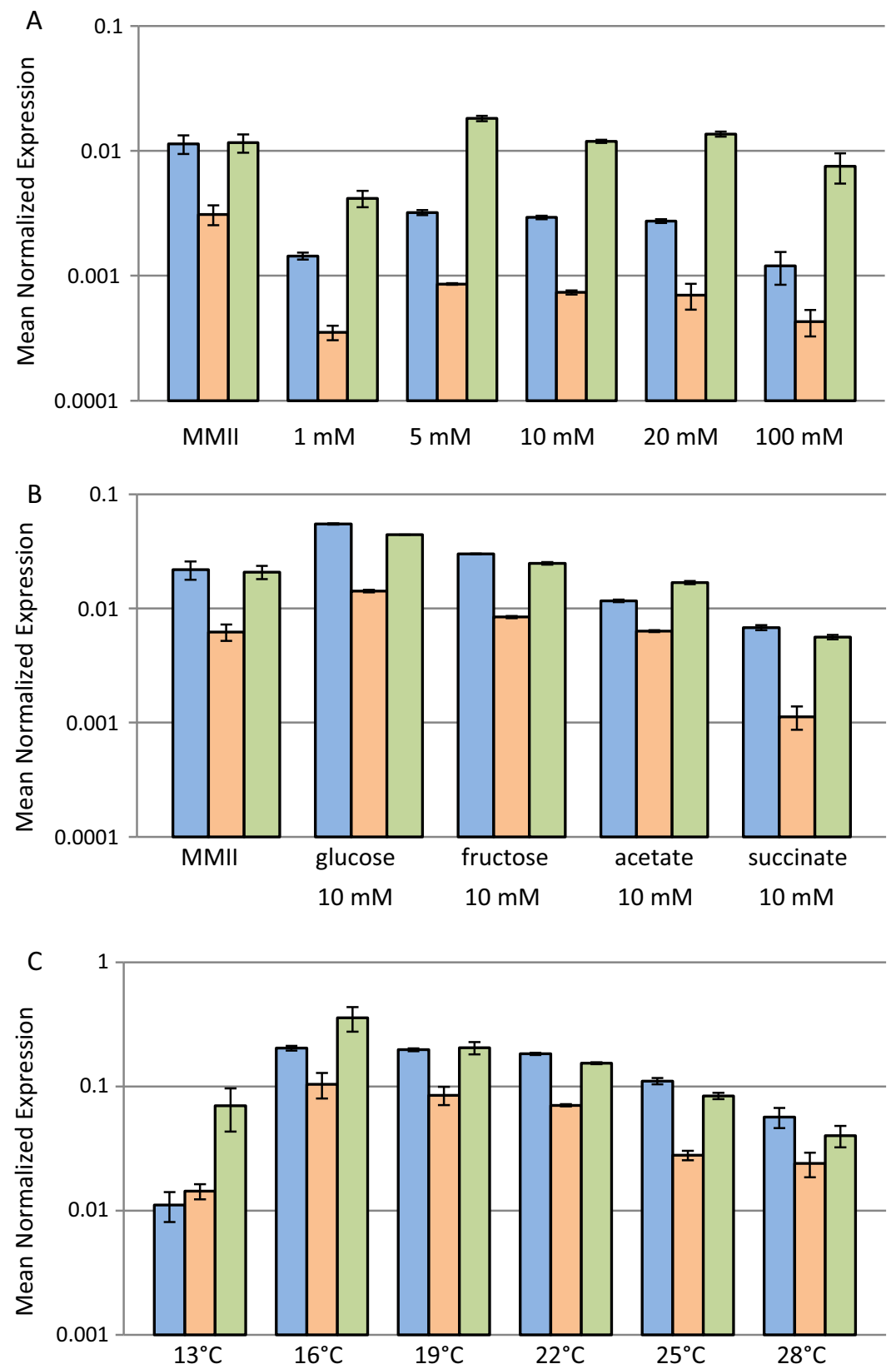

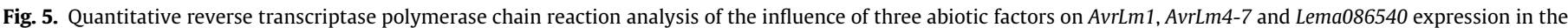

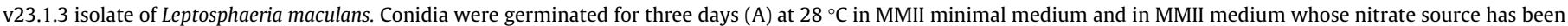

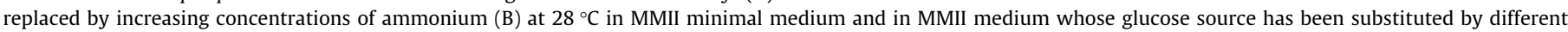

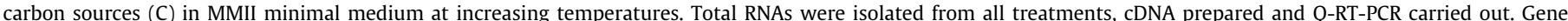

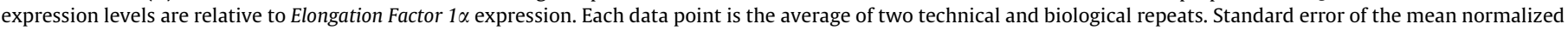
expression is indicated by error bars. $\square$ AvrLm $1 \square$ AvrLm4-7 $\square$ Lema086540. 
3.7. Effect of four physico-chemical factors on the expression of genes encoding effectors

Our data showed the growth medium pH may impact expression of effector genes. Other factors described in the literature to induce effector genes expression include temperature, carbon and nitrogen sources (see discussion section). To confirm the influence of $\mathrm{pH}$ on expression of fungal effector genes, conidia of $L$. maculans were inoculated to MMII liquid medium with $\mathrm{pH}$ ranging between 5.0 and 7.5. Compared to MMII medium at pH 5.0, a modest up-regulation of transcript levels of AvrLm1, AvrLm4-7 and Lema086540 was detected at pH 5.5 (2.5-, 4.3-, 2.9-fold vs control) (Supplemental Fig. S4). This increase was followed at higher $\mathrm{pH}$ by a continuous decrease of expression of these three genes and their lowest transcript levels were obtained at pH 7.5 (Supplemental Fig. S4).

To evaluate the influence of nitrogen source, nitrate in MMII medium was replaced by ammonium at increasing concentrations ranging from $1 \mathrm{mM}$ to $100 \mathrm{mM}$. In all cases, this $\mathrm{N}$ source was found to be less conducive than nitrate to expression of effector genes AvrLm1 and AvrLm4-7 while its effect was low on the expression of Lema086540 (Fig. 5A). The importance of the carbon source was then evaluated by decreasing the concentration of glucose which is the carbon source in liquid MMII medium from $110 \mathrm{mM}$ to $10 \mathrm{mM}$ and by replacing glucose with either another monosaccharide or four different sodium salt of acids. The ability of conidia to grow in media with these different carbon sources was firstly evaluated and the fungal mycelium collected after 4 days of incubation was dried and weighted. As no differences were found between the dry weight of mycelium collected in MMII medium containing glucose at either $110 \mathrm{mM}$ or $10 \mathrm{mM}$, the next experiments were performed in media supplied with carbon source at $10 \mathrm{mM}$. Fructose was an adequate carbon source as a comparable dry weight of mycelium to that obtained with glucose was collected (data not shown). Sodium acetate and sodium succinate were carbon sources less favorable to fungal growth and only two thirds and one third of the dry weight of mycelium compared to glucose were obtained. Finally, no fungal growth was obtained with medium containing either sodium propionate or sodium citrate as sole carbon source (data not shown). With the main exception of sodium succinate, the effect of the carbon source on effector gene expression was modest, with expression levels similar to those observed in regular MMII medium when fructose and sodium acetate were used as the carbon source at $10 \mathrm{mM}$, and only a slight ca; 2.0-fold increase of expression for reduced glucose concentration compared to that of regular MMII medium (Fig. 5B).

The fourth evaluated parameter was growth temperature. As all the previous experiments were performed at $28^{\circ} \mathrm{C}$, we decided to test five lower temperatures ranging from $13^{\circ} \mathrm{C}$ to $25^{\circ} \mathrm{C}$. Expression profiles of the three genes were very similar and their maximal and minimal transcript levels were obtained at $16^{\circ} \mathrm{C}$ and $13^{\circ} \mathrm{C}$, respectively (Fig. 5C). The more conducive temperature, $16{ }^{\circ} \mathrm{C}$ (five days of growth) or $19{ }^{\circ} \mathrm{C}$ (four days of growth) allowed a 3.0- to 4.3-fold increase in gene expression compared to the usual inoculation temperature of $28^{\circ} \mathrm{C}$, while the less favorable one only lead to a 1.7-fold reduction of expression (for AvrLm4-7 and Lema086540) (Fig. 5C). AvrLm1 expression, however, was more susceptible to reduced temperature with ca. 5.0-fold reduction at $13^{\circ} \mathrm{C}$ compared to $28^{\circ} \mathrm{C}$ (Fig. 5C).

\section{Discussion}

In this study, we evaluated if biotic and abiotic factors can favour the expression of genes encoding effectors during axenic growth. Our data show that physico-chemical parameters can influence the expression of genes encoding effectors in L. maculans and indicate that changes in some growth conditions and medium composition, along with inclusion of antibiotics could be used to increase expression of some effector genes in culture condition.

The factor most conducive to enhanced expression was cycloheximide, but, for a similar genome location within AT-isochores, the impact of cycloheximide on candidate effector genes was evident for five of them but not for three other ones. Among the factors tested, no effect on the expression profiles of three selected effector genes was detected for three biotic factors (puromycin, hygromycin B, nourseothricin). For the seven other factors impacting the transcription level of these genes, the expression profiles obtained were overall highly similar with only minor exceptions. Low variations of the effector expression levels were observed for three abiotic factors ( $\mathrm{pH}$, carbon source and temperature). Together, these data indicate that the regulation of the expression of effector genes is complex and multifactorial suggesting growth conditions and possible addition of antibiotics to the medium will induce a gene-dependent response.

In addition to nitrogen source, three abiotic factors ( $\mathrm{pH}$, carbon source and temperature) were found here to impact moderately the expression of genes encoding $L$. maculans effectors. The importance of nitrogen source on the expression of Avr9 in the tomato pathogen Cladosporium fulvum has already been reported (Van den Ackerveken et al., 1994). The Avr9 gene encodes an avirulence protein and its expression is strongly induced when the nitrogen concentration of different sources (nitrate, ammonium, glutamate, glutamine) in synthetic liquid medium is below $1 \mathrm{mM}$. Moreover, the global nitrogen response factor NRF1 of $C$. fulvum is a major regulator of Avr9 expression (Perez-Garcia et al., 2001). The in vitro expression profile of AvrLm1, AvrLm4-7 and Lema086540 was the opposite of that of Avr9 with no induction at $1 \mathrm{mM}$ ammonium and no repression at $23 \mathrm{mM}$ nitrate. However, the in vitro expression pattern of Avr9 is probably more the exception than the rule as the expression of three other genes encoding effectors of $C$. fulvum (avr4, ecp1, ecp2) was also not induced under limited concentration of nitrogen (Perez-Garcia et al., 2001).

To our knowledge, the incidence of other abiotic factors on expression of SSP-encoding genes has not been investigated in phytopathogenic fungi but some data are available for apoplastresiding phytopathogenic bacteria. For example, bacterial hypersensitive response and pathogenicity ( $h r p$ ) genes encoding component proteins of the type III secretion system have been shown to be subjected to environmental regulation. These genes are essential for the pathogenicity of numerous Gram-negative plant bacterial pathogens, including Pseudomonas syringae, Xanthomonas sp., Erwinia sp., and Ralstonia solenacearum and can also act as avirulence determinants. Induction of the expression of avirulence and hrp genes is observed during bacterial growth in synthetic minimal media, where the level of expression depends on the nature of the carbon source (Huynh et al., 1989; Arlat et al., 1991, 1992; Rahme et al., 1992; Wei et al., 1992; Schulte and Bonas, 1992). In some bacterial species, other abiotic factors, such as temperature, $\mathrm{pH}$ and nitrogen source, also induce hrp and avirulence genes (Rahme et al., 1992; Wei et al., 1992; Schulte and Bonas, 1992; Xiao et al., 1992; van Dijk et al., 1999). In contrast, the expression of most hrp genes is suppressed during bacterial growth in complex media (Arlat et al., 1991; Rahme et al., 1992; Schulte and Bonas, 1992; Xiao et al., 1992).

Similar responses of effector genes were found in $L$. maculans. Overall, it appears that physico-chemical parameters such as an acidic pH (around 5.5-6.0), a moderate temperature (around 16$22{ }^{\circ} \mathrm{C}$ ) and an ammonium concentration varying from 5 to $20 \mathrm{mM}$ are favourable for the expression of both the bacterial effector genes and the three fungal genes AvrLm1, AvrLm4-7 and Lema086540. However, differences exist for the carbon sources. 
Glucose has a positive effect on the expression of the fungal effector genes but represses strongly the expression of E. amylovora hrp genes (Wei et al., 1992). Fructose which is an adequate substrate for $L$. maculans has very little activity in $R$. solanacearum (Arlat et al., 1992). The tricarboxylic cycle intermediate citrate which is very efficient in $P$. syringae $p v$ phaseolicola and moderately efficient in $R$. solanacearum (Arlat et al., 1992; Rahme et al., 1992) cannot be used as sole carbon source by $L$. maculans.

All these data indicate that the minimal media used for L. maculans and bacteria probably mimics more closely the physiological environment encountered by these microorganisms during plant infection. Moreover, for procayotes and an eucaryote that have essentially an apoplastic life, the same physiological parameters important for the regulation of bacterial and fungal effectors expression are found. Nevertheless, specificities exist also for each phytopathogen indicating that this regulation is a complex process probably depending on the host plant and mediated by several different interacting mechanisms integrating availability of nutrients and cellular metabolism.

We establish here that antibiotics can impact the expression of fungal effector genes. These antibiotics belong to two different families, aminoglycosides and bleomycin family. Aminoglycosides are protein synthesis inhibitors that bind to specific sites on the ribosome whereas the members of the bleomycin-class of antibiotics drive DSBs formation (Suzuki et al., 1970; Hansen et al., 2003). The fungal growth reduction observed with increasing concentration of phleomycin was correlated to the expression level of the three effector genes i.e., the stronger the growth reduction, the higher the increase of expression. This correlation apparently does not exist for aminoglycosides as the peak of effector gene expression was obtained at antibiotic concentrations ten times lower than that inhibiting most strongly the fungal growth. Surprisingly, no change in the expression of the three effector genes was also observed with puromycin which had nevertheless a stronger impact on fungal growth than anisomycin at the three concentrations tested. As three aminoglycosides and phleomycin upregulated AvrLm1, AvrLm4-7 and Lema086540 expression, these results indicate that different types of intracellular stresses activate the transcription of effector-encoding genes in L. maculans. A few studies have already shown that exposure of fungi to aminoglycosides can lead to a deregulation of genes expression, including secondary metabolite gene clusters, but, being mostly analyzed on model, non-pathogenic species, the genes identified did not encompass putative effectors (Gladyshev and Arkhipova, 2011; Sakuda et al., 2000; Yoshinari et al., 2010). It now is of interest to determine if the effect of cycloheximide or phleomycin could be similar in other fungal pathogens and thus be a convenient tool for effector identification and analysis.

Our data indicate that the treatment of $L$. maculans with cycloheximide did not induce a significant variation of HP1 and DIM5 expression levels. However, a regulation at the posttranscriptional level of these two genes may induce chromatin changes resulting in a lift of the epigenetic control of expression of some effector genes. This question deserves further investigation.

An interesting question is to determine if the in vitro conditions found to trigger the expression of the three selected effectors may correspond to biotic or abiotic conditions prevailing in the natural environment of the fungus. Temperature is an important parameter for germination of ascospores of $L$. maculans as well as germ tube elongation on leaf surfaces and for the formation of leaf lesions (Toscano-Underwood et al., 2001; Huang et al., 2003). In controlled-environment experiments performed with increasing temperature from $5{ }^{\circ} \mathrm{C}$ to $20^{\circ} \mathrm{C}$, optimal temperatures of $15-$ $20^{\circ} \mathrm{C}$ were reported. Temperature is also critical for the expression of some resistance to $L$. maculans in B. napus, with, for example, a lesser efficiency of the Rlm6 resistance at temperatures above $25^{\circ} \mathrm{C}$ (Huang et al., 2006). We have established that the temperature also influences the transcription level of effectors and the optimum of $16^{\circ} \mathrm{C}$ coincides with the range of optimal temperatures previously reported for ascopore germination and leaf lesion development (Huang et al., 2003). For oilseed rape, an apoplastic pH of 5.8 and an ammonium concentration of $1.3 \mathrm{mM}$ were measured in young leaves of $B$. napus cv Global but not data for sugar concentrations are currently available (Husted and Schjoerring, 1995). These $\mathrm{pH}$ and $\mathrm{NH}_{4}^{+}$concentration values are respectively, slightly higher and lower than the optimal values we found in our in vitro experiments. However, the apoplastic pH as well as carbohydrate composition and nitrogen content are subject to variation during the intercellular growth of biotrophic fungi in plant host. For example, a pH increase has been reported during the infection of barley leaves with the brown rust fungus (Tetlow and Farrar, 1993). A change of apoplastic pH is important because the activities of host and fungal cell wall invertases could be altered and subsequent rates of hexose-uptake by the fungus or the host cells could be modified. This may in turn impact the apoplastic sugar content. Such changes in the concentration of sugars like sucrose, glucose and fructose have been reported during the plant infection by biotrophic fungi (Hwang et al., 1989; Joosten et al., 1990). In the case of $L$. maculans, the germination of ascopores on the leaf surface is followed by the penetration of the leaf by mycelium hypha that feed in the apoplast. At some stage there, signals of still unknown origin will enable chromatin decondensation and availability of effector genes located in AT-isochores to other regulatory factors (Soyer et al., 2014). The colonization of the apoplast is then concomitant to a modification of the physiological parameters encountered by the fungus that, in this new environment, are favourable to the expression of effector genes. In addition, a fungal-induced change in the $\mathrm{pH}$ as well as variation of nitrogen and sugar content of the apoplast may result in an optimization of the physiological parameters of this ecological niche enabling a highest expression of effector genes. Thus, changes of the apoplastic space conditions during the different stages of fungal infection may contribute to the differential pattern of expression observed for effectors genes. Moreover, an interplay between physico-chemical parameters and plant-derived signals is likely to fine-tune fungal effector gene expression.

A second question is about the biological significance of the response to bacterial antibiotics. Bacteria are present everywhere in the environment (water, soil, rhizosphere). On plants, they live at the leaf surface but endophytic bacteria can also colonize the apoplast and stem as well as root tissues. At present, the bacterial communities living on $B$. napus plants have not been characterized in the wild but endophytic Streptomyces have been isolated from stems of B. oleracea indicating that bacteria can colonize Brassicaceae (Sardi et al., 1992). Therefore, at all the steps of its life cycle, L. maculans can meet bacteria in its vicinity. This is especially true during its saprotrophic stage when it survives on stem residues for many years following harvest and which is crucial in the fungal life cycle being the place where sexual reproduction occurs. The six aminoglycosides and phleomycin we used in our study are produced by seven different soil bacteria belonging all to Streptomyces. In natural conditions, one may hypothesize that the recognition of L. maculans by each of these telluric bacteria could activate the production of antibiotics that will be released in the fungal environment. In response to this chemical attack, the fungus will use different strategies according to the type of antibiotics: either activation of cellular mechanisms leading to a reduction of the intracellular concentration of the antibiotic or induction of other transcriptional pathways leading to the production of bioactive compounds. Our transcriptomic analysis shows that numerous candidate effector genes are included in the set of genes 
up-regulated by cycloheximide treatment including a NRPSencoding gene [NRPS11 (Lema012390)] involved in the synthesis of a secondary metabolite and located in a subtelomeric AT-rich region as well as four SSP-encoding genes (Lema036180, AT06extSuperContig5.1, Lema083940, Lema054900) which are in the top 50 up-regulated genes. Some evolutionary studies suggest effector may have had a primary antimicrobial activity before being recycled in the course of evolution as pathogenicity factors (Rovenich et al., 2014). The possibility that one of these putatively secreted proteins may have an antibacterial function deserves further investigation.

In conclusion, this study reveals that biotic and abiotic factors impact the expression of effector genes of a filamentous fungal pathogen. Interestingly, the same factors have been reported to influence the expression of bacterial effectors. This suggests that the same physico-chemical parameters regulating the effector expression of an eukaryote and prokaryotes correspond to the same physiological conditions met by these pathogens colonizing the same ecological niche, the apoplasm.

This research did not receive any specific grant from funding agencies in the public, commercial, or not-for-profit sectors.

\section{Appendix A. Supplementary material}

Supplementary data associated with this article can be found, in the online version, at http://dx.doi.org/10.1016/j.fgb.2016.12.008.

\section{References}

Amselem, J., Cuomo, C.A., van Kan, J.A., Viaud, M., Benito, E.P., Couloux, A., Coutinho, P.M., de Vries, R.P., Dyer, P.S., Fillinger, S., Fournier, E., Gout, L., Hahn, M., Kohn, L., Lapalu, N., Plummer, K.M., Pradier, J.M., Quévillon, E., Sharon, A., Simon, A. ten Have, A., Tudzynski, B., Tudzynski, P., Wincker, P., Andrew, M., Anthouard V., Beever, R.E., Beffa, R., Benoit, I., Bouzid, O., Brault, B., Chen, Z., Choquer, M., Collémare, J., Cotton, P., Danchin, E.G., Da Silva, C., Gautier, A., Giraud, C., Giraud, T., Gonzalez, C., Grossetete, S., Güldener, U., Henrissat, B., Howlett, B.J., Kodira, C., Kretschmer, M., Lappartient, A., Leroch, M., Levis, C., Mauceli, E., Neuvéglise, C., Oeser, B., Pearson, M., Poulain, J., Poussereau, N., Quesneville, H., Rascle, C. Schumacher, J., Ségurens, B., Sexton, A., Silva, E., Sirven, C., Soanes, D.M., Talbot, N.J., Templeton, M., Yandava, C., Yarden, O., Zeng, Q., Rollins, J.A., Lebrun, M.H., Dickman, M., 2011. Genomic analysis of the necrotrophic fungal pathogens Sclerotinia sclerotiorum and Botrytis cinerea. PLoS Genet. 7, e1002230.

Arlat, M., Gough, C.L., Barber, C.E., Boucher, C., Daniels, M.J., 1991. Xanthomonas campestris contains a cluster of hrp genes related to the larger hrp cluster of Pseudomonas solanacearum. Mol. Plant-Microbe Interact. 6, 593-601.

Arlat, M., Gough, C.L., Zischek, C., Barberis, P.A., Trigalet, A., Boucher, C.A., 1992 Transcriptional organization and expression of the large hrp gene cluster of Pseudomonas solanacearum. Mol. Plant-Microbe Interact. 5, 187-193.

Balesdent, M.H., Attard, A., Kuhn, A.L., Rouxel, T., 2002. New avirulence genes in the phytopathogenic fungus Leptosphaeria maculans. Phytopathology 92, 11221133.

Balesdent, M.H., Fudal, I., Ollivier, B., Bally, P., Grandaubert, J., Eber, F., Chevre, A.M., Leflon, M., Rouxel, T., 2013. The dispensable chromosome of Leptosphaeria maculans shelters an effector gene conferring avirulence towards Brassica rapa. New Phytol. 198, 887-898.

Bolton, M.D., van Esse, H.P., Vossen, J.H., de Jonge, R., Stergiopoulos, I., Stulemeijer, I J.E., van den Berg, G.C.M., Borras-Hidalgo, O., Dekker, H.L., de Koster, C.G., de Wit, P.J.G.M., Joosten, M.H.A.J., Thomma, B.P.H.J., 2008. The novel Cladosporium fulvum lysin motif effector Ecp6 is a virulence effector with orthologues in other fungal species. Mol. Microbiol. 69, 119-136.

Bourras, S., Meyer, M., Grandaubert, J., Lapalu, N., Fudal, I., Linglin, J., Ollivier, B. Blaise, F., Balesdent, M.H., Rouxel, T., 2012. Incidence of genome structure, DNA asymmetry, and cell physiology on T-DNA integration in chromosomes of the phytopathogenic fungus Leptosphaeria maculans. G3: Genes|Genomes|Genetics 2, 891-904.

Cantu, D., Segovia, V., MacLean, D., Bayles, R., Chen, X., Kamoun, S., Dubcovsky, J. Saunders, D.G., Uauy, C., 2013. Genome analyses of the wheat yellow (stripe) rust pathogen Puccinia striiformis f. sp. tritici reveal polymorphic and haustorial expressed secreted proteins as candidate effectors. BMC Genom. 14, 270.

de Hoon, M.J., Imoto, S., Nolan, J., Miyano, S., 2004. Open source clustering software. Bioinformatics 20, 1453-1454.

Dobon, A., Bunting, D.C.E., Cabrera-Quia, L.E., Uauy, C., Saunders, D.G.O., 2016. The host-pathogen interaction between wheat and yellow rust induces temporally coordinated waves of gene expression. BMC Genom. 17, 380.

Dong, Y., Li, Y., Zhao, M., Jing, M., Liu, X., Liu, M., Guo, X., Zhang, X., Chen, Y., Liu, Y., Liu, Y., Ye, W., Zhang, H., Wang, Y., Zheng, X., Wang, P., Zhang, Z., 2015. Global genome and transcriptome analyses of Magnaporthe oryzae epidemic isolate
98-06 uncover novel effectors and pathogenicity-related genes, revealing gene gain and lose dynamics in genome evolution. PLoS Pathog. 11, e1004801.

Duplessis, S., Cuomo, C.A., Lin, Y.C., Aerts, A., Tisserant, E., Veneault-Fourrey, C., Joly, D.L., Hacquard, S., Amselem, J., Cantarel, B.L., Chiu, R., Coutinho, P.M., Feau, N., Field, M., Frey, P., Gelhaye, E., Goldberg, J., Grabherr, M.G., Kodira, C.D., Kohler, A., Kües, U., Lindquist, E.A., Lucas, S.M., Mago, R., Mauceli, E., Morin, E., Murat, C., Pangilinan, J.L., Park, R., Pearson, M., Quesneville, H., Rouhier, N., Sakthikumar, S., Salamov, A.A., Schmutz, J., Selles, B., Shapiro, H., Tanguay, P., Tuskan, G.A., Henrissat, B., Van de Peer, Y., Rouzé, P., Ellis, J.G., Dodds, P.N., Schein, J.E., Zhong S., Hamelin, R.C., Grigoriev, I.V., Szabo, L.J., Martin, F., 2011. Obligate biotrophy features unraveled by the genome analysis of rust fungi. Proc. Natl. Acad. Sci. U. S.A. 108, 9166-9171.

Fudal, I., Ross, S., Gout, L., Blaise, F., Kuhn, M.L., Eckert, M.R., Cattolico, L., BernardSamain, S., Balesdent, M.H., Rouxel, T., 2007. Heterochromatin-like regions as ecological niches for avirulence genes in the Leptosphaeria maculans genome: Map-based cloning of AvrLm6. Mol. Plant-Microbe Interact. 20, 459-470.

Gervais, J., Plissonneau, C., Linglin, J., Meyer, M., Labadie, K., Cruaud, C., Fudal, I., Rouxel, T., Balesdent, M.H., 2016. Different waves of effector genes with contrasted genomics location are expressed by Leptosphaeria maculans during cotyledon and stem colonization of oilseed rape. Mol. Plant. Pathol. http://dx. doi.org/10.1111/mpp.12464.

Ghanbarnia, K., Fudal, I., Larkan, N.J., Links, M.G., Balesdent, M.H., Profotova, B., Fernando, W.G.D., Rouxel, T., Borhan, M.H., 2014. Rapid identification of the Leptosphaeria maculans avirulence gene AvrLm2 using and intraspecific comparative genomics approach. Mol. Plant Pathol. 16, 699-709.

Gladyshev, E.A., Arkhipova, I.R., 2011. A widespread class of reverse transcriptaserelated cellular gene. Proc. Natl. Acad. Sci. U.S.A. 108, 20311-20316.

Gout, L., Fudal, I., Kuhn, M.L., Blaise, F., Eckert, M., Cattolico, L., Balesdent, M.H., Rouxel, T., 2006. Lost in the middle of nowhere: the AvrLm1 avirulence gene of the dothideomycete Leptosphaeria maculans. Mol. Microbiol. 60, 67-80.

Guyon, K., Balague, C., Roby, D., Raffaele, S., 2014. Secretome analysis reveals effector candidates associated with broad host range necrotrophy in the fungal plant pathogen Sclerotinia sclerotiorum. BMC Genom. 15, 336.

Hacquard, S., Joly, D.L., Lin, Y.C., Tisserant, E., Feau, N., Delaruelle, C., Legué, V., Kohler, A., Tanguay, P., Petre, B., Frey, P., Van de Peer, Y., Rouzé, P., Martin, F., Hamelin, R.C., Duplessis, S., 2012. A comprehensive analysis of genes encoding small secreted proteins identifies candidate effectors in Melampsora laricipopulina (Poplar Leaf Rust). Mol. Plant Microbe Interact. 25, 279-293.

Haddadi, P., Ma, L., Wang, H., Borhan, M.H., 2016. Genome-wide transcriptomic analyses provide insights into the lifestyle transition and effector repertoire of Leptosphaeria maculans during the colonization of Brassica napus seedlings. Mol. Plant Pathol. http://dx.doi.org/10.1111/mpp.12356.

Hansen, J.L., Moore, P.B., Steitz, T.A., 2003. Structures of five antibiotics bound at the peptidyl transferase center of the large ribosomal subunit. J. Mol. Biol. 330, $1061-1075$.

Hogenhout, S.A., Van der Hoorn, R.A., Terauchi, R., Kamoun, S., 2009. Emerging concepts in effector biology of plant-associated organisms. Mol. Plant Microbe Interact. 22, 115-122.

Huang, Y.J., Toscano-Underwood, C., Fitt, B.D.L., Hu, X.J., Hall, A.M., 2003. Effects of temperature on ascospore germination and penetration of oilseed rape (Brassica napus) leaves by A- or B-group Leptosphaeria maculans. Plant. Pathol. 52, 245255

Huang, Y.J., Evans, N., Li, Z.Q., Eckert, M., Chevre, A.M., Renard, M., Fitt, B.D., 2006. Temperature and leaf wetness duration affect phenotypic expression of Rlm6mediated resistance to Leptosphaeria maculans in Brassica napus. New Phytol. $170,129-141$

Husted, S., Schjoerring, J.K., 1995. Apoplastic pH and ammonium concentration in leaves of Brassica napus L. Plant Physiol. 109, 1453-1460.

Huynh, T.V., Dahlbeck, D., Staskawicz, B.J., 1989. Bacterial blight of soybean: regulation of a pathogen gene determining host cultivar specificity. Science 245 , 1374-1377.

Hwang, B.K., Kim, K.D., Kim, Y.B., 1989. Carbohydrate composition and acid invertase activity in rice leaves infected with Pyricularia oryzae. J. Phytopathol. 125, 124-132.

Joosten, M.H.A.J., Hendrickx, L.J.M., De Wit, P.J.G.M., 1990. Carbohydrate composition of apoplastic fluids isolated from tomato leaves inoculated with virulent or avirulent races of Cladosporium fulvum (syn. Fulvia fulva). Neth. J. Plant Pathol. 96, 103-112.

Livak, K.J., Schmittgen, T.D., 2001. Analysis of relative gene expression data using real-time quantitative PCR and the 2(-Delta Delta C(T)) method. Methods 25, 402-408.

Lo Presti, L., Lanver, D., Schweizer, G., Tanaka, S., Liang, L., Tollot, M., Zuccaro, A., Reissmann, S., Kahmann, R., 2015. Fungal effectors and plant susceptibility. Annu. Rev. Plant Biol. 66, 513-545.

Love, M.I., Huber, W., Anders, S., 2014. Moderated estimation of fold change and dispersion for RNA-seq data with DESeq2. Genome Biol. 15, 550.

Ma, L.J., van der Does, H.C., Borkovich, K.A., Coleman, J.J., Daboussi, M.J., Di Pietro, A., Dufresne, M., Freitag, M., Grabherr, M., Henrissat, B., Houterman, P.M., Kang S. Shim, W.B., Woloshuk, C., Xie, X., Xu, J.R., Antoniw, J., Baker, S.E., Bluhm, B.H., Breakspear, A., Brown, D.W., Butchko, R.A., Chapman, S., Coulson, R., Coutinho, P. M., Danchin, E.G., Diener, A., Gale, L.R., Gardiner, D.M., Goff, S., HammondKosack, K.E., Hilburn, K., Hua-Van, A., Jonkers, W., Kazan, K., Kodira, C.D. Koehrsen, M., Kumar, L., Lee, Y.H., Li, L., Manners, J.M., Miranda-Saavedra, D. Mukherjee, M., Park, G., Park, J., Park, S.Y., Proctor, R.H., Regev, A., Ruiz-Roldan, M.C., Sain, D., Sakthikumar, S., Sykes, S., Schwartz, D.C., Turgeon, B.G., Wapinski, I., Yoder, O., Young, S., Zeng, Q., Zhou, S., Galagan, J., Cuomo, C.A., Kistler, H.C., 
Rep, 2010. Comparative genomics reveals mobile pathogenicity chromosomes in Fusarium. Nature 464, 367-373.

Masachis, S., Segorbe, D., Turra, D., Leon-Ruiz, M., Fürst, U., El Ghalid, M., Leonard, G., Lopez-Berges, M.S., Richards, T.A., Felix, G., Di Pietro, A., 2016. A fungal pathogen secretes plant alkalinizing peptides to increase infection. Nat. Microbiol. http:// dx.doi.org/10.1038/NMICROBIOL.2016.43.

Mirzadi Gohari, A., Ware, S.B., Wittenberg, A.H.J., Mehrabi, R., Ben M'Barek, S., Verstappen, E.C.P., van der Lee, T.A.J., Robert, O., Schouten, H.J., de Wit, P.P.J.G. M., Kema, G.H.J., 2015. Effector discovery in the fungal wheat pathogen Zymoseptoria tritici. Mol. Plant Pathol. 16, 931-945.

Mosquera, G., Giraldo, M., Khang, C.H., Coughlan, S., Valent, B., 2009. Interaction transcriptome analysis identifies Magnaporthe oryzae BAS1-4 as biotrophyassociated secreted proteins in rice blast disease. Plant Cell 21, 1273-1290.

O'Connell, R.J., Thon, M.R., Hacquard, S., Amyotte, S.G., Kleemann, J., Torres, M.F., Damm, U., Buiate, E.A., Epstein, L., Alkan, N., Altmüller, J., Alvarado-Balderrama, L., Bauser, C.A., Becker, C., Birren, B.W., Chen, Z., Choi, J., Crouch, J.A., Duvick, J.P. Farman, M.A., Gan, P., Heiman, D., Henrissat, B., Howard, R.J., Kabbage, M., Koch, C., Kracher, B., Kubo, Y., Law, A.D., Lebrun, M.H., Lee, Y.H., Miyara, I., Moore, N., Neumann, U., Nordström, K., Panaccione, D.G., Panstruga, R., Place, M., Proctor, R.H., Prusky, D., Rech, G., Reinhardt, R., Rollins, J.A., Rounsley, S., Schardl, C.L., Schwartz, D.C., Shenoy, N., Shirasu, K., Sikhakolli, U.R., Stüber, K., Sukno, S.A., Sweigard, J.A., Takano, Y., Takahara, H., Trail, F., van der Does, H.C., Voll, L.M., Will, I., Young, S., Zeng, Q., Zhang, J., Zhou, S., Dickman, M.B., Schulze-Lefert, P., Loren, Ver., van Themaat, E., Ma, L.J., Vaillancourt, L.J., 2012. Lifestyle transitions in plant pathogenic Colletotrichum fungi deciphered by genome and transcriptome analyses. Nat. Genet. 44, 1060-1065.

Ohm, R.A., Feau, N., Henrissat, B., Schoch, C.L., Horwitz, B.A., Barry, K.W., Condon, B. J., Copeland, A.C., Dhillon, B., Glaser, F., Hesse, C.N., Kosti, I., LaButti, K., Lindquist, E.A., Lucas, S., Salamov, A.A., Bradshaw, R.E., Ciuffetti, L., Hamelin, R.C., Kema, G. H., Lawrence, C., Scott, J.A., Spatafora, J.W., Turgeon, B.G., de Wit, P.J., Zhong, S. Goodwin, S.B., Grigoriev, I.V., 2012. Diverse lifestyles and strategies of plant pathogenesis encoded in the genomes of eighteen Dothideomycetes fungi. PLoS Pathog. 8, e1003037.

Parlange, F., Daverdin, G., Fudal, I., Kuhn, M.L., Balesdent, M.H., Blaise, F., GrezesBesset, B., Rouxel, T., 2009. Leptosphaeria maculans avirulence gene AvrLm4-7 confers a dual recognition specificity by the $R \operatorname{lm} 4$ and $R \operatorname{lm} 7$ resistance genes of oilseed rape, and circumvents Rlm4-mediated recognition through a single amino acid change. Mol. Microbiol. 71, 851-863.

Perez-Garcia, A., Snoeijers, S.S., Joosten, M.H.A., Goosen, T., De Wit, P.J.G.M., 2001. Expression of the avirulence gene Avr9 of the fungal tomato pathogen Cladosporium fulvum is regulated by the global nitrogen response factor NRF1. Mol. Plant-Microbe Interact. 14, 316-325.

Plissonneau, C., Daverdin, G., Ollivier, B., Blaise, F., Degrave, A., Fudal, I., Rouxel, T., Balesdent, M.H., 2016. A game of hide and seek between avirulence genes AvrLm4-7 and AvrLm3 in Leptosphaeria maculans. New Phytol. 209, 1613-1624.

Rahme, L.G., Mindrinos, M.N., Panopoulos, N.J., 1992. Plant and environmental sensory signals control the expression of hrp genes in Pseudomonas syringae pv phaseolicola. J. Bacteriol. 174, 3499-3507.

Rovenich, H., Boshoven, J.C., Thomma, B.P., 2014. Filamentous pathogen effector functions: of pathogens, hosts and microbiomes. Curr. Opin. Plant Biol. 20, 96103.

Rouxel, T., Balesdent, M.H., 2005. The stem canker (blackleg) fungus, Leptosphaeria maculans, enters the genomic era. Mol. Plant Pathol. 6, 225-241.

Rouxel, T., Grandaubert, J., Hane, J.K., Hoede, C., van de Wouw, A.P., Couloux, A., Dominguez, V., Anthouard, V., Bally, P., Bourras, S., Cozijnsen, A.J., Ciuffetti, L.M., Degrave, A., Dilmaghani, A., Duret, L., Fudal, I., Goodwin, S.B., Gout, L., Glaser, N., Linglin, J., Kema, G.H., Lapalu, N., Lawrence, C.B., May, K., Meyer, M., Ollivier, B., Poulain, J., Schoch, C.L., Simon, A., Spatafora, J.W., Stachowiak, A., Turgeon, B.G., Tyler, B.M., Vincent, D., Weissenbach, J., Amselem, J., Quesneville, H., Oliver, R.P., Wincker, P., Balesdent, M.H., Howlett, B.J., 2011. Effector diversification within compartments of the Leptosphaeria maculans genome affected by RepeatInduced Point mutations. Nat. Commun. 2, n202.

Sakuda, S., Ono, M., Ikeda, H., Nakamura, T., Inagaki, Y., Kawachi, R., Nakayama, J., Suzuki, A., Isogai, A., Nagasawa, H., 2000. Blasticidin A as an inhibitor of aflatoxin production in Aspergillus parasiticus. J. Antibiot. 53, 1265-1271.

Saldanha, A.J., 2004. Java Treeview-extensible visualization of microarray data. Bioinformatics 20, 3246-3248.
Sardi, P., Saracchi, M., Quaroni, S., Petrolini, B., Borgonovi, G.E., Merli, S., 1992. Isolation of endophytic Streptomyces strains from surface-sterilized roots. Appl. Environ. Microbiol. 58, 2691-2693.

Schneider-Poetsch, T., Ju, J., Eyler, D.E., Dang, Y., Bhat, S., Merrick, W.C., Green, R., Shen, B., Liu, J.O., 2010. Inhibition of eukaryotic translation elongation by cycloheximide and lactimidomycin. Nat. Chem. Biol. 6, 209-217.

Schulte, R., Bonas, U., 1992. A Xanthomonas pathogenicity locus is induced by sucrose and sulphur containing amino acids. Plant Cell 4, 79-86.

Soyer, J.L., El Ghalid, M., Glaser, N., Ollivier, B., Linglin, J., Grandaubert, J., Balesdent, M.H., Connolly, L.R., Freitag, M., Rouxel, T., Fudal, I., 2014. Epigenetic control of effector gene expression in the plant pathogenic fungus Leptosphaeria maculans. PLoS Genet. 10, e1004227.

Spanu, P.D., Abbott, J.C., Amselem, J., Burgis, T.A., Soanes, D.M., Stüber, K., Loren, Ver., van Themaat, E., Brown, J.K., Butcher, S.A., Gurr, S.J., Lebrun, M.H., Ridout, C. J., Schulze-Lefert, P., Talbot, N.J., Ahmadinejad, N., Ametz, C., Barton, G.R., Benjdia, M., Bidzinski, P., Bindschedler, L.V., Both, M., Brewer, M.T., CadleDavidson, L., Cadle-Davidson, M.M., Collemare, J., Cramer, R., Frenkel, O. Godfrey, D., Harriman, J., Hoede, C., King, B.C., Klages, S., Kleemann, J., Knoll, D. Koti, P.S., Kreplak, J., López-Ruiz, F.J., Lu, X., Maekawa, T., Mahanil, S., Micali, C., Milgroom, M.G., Montana, G., Noir, S., O'Connell, R.J., Oberhaensli, S., Parlange, F., Pedersen, C., Quesneville, H., Reinhardt, R., Rott, M., Sacristán, S., Schmidt, S. M., Schön, M., Skamnioti, P., Sommer, H., Stephens, A., Takahara, H., ThordalChristensen, H., Vigouroux, M., Wessling, R., Wicker, T., Panstruga, R., 2010. Genome expansion and gene loss in powdery mildew fungi reveal tradeoffs in extreme parasitism. Science 330, 1543-1546.

Suzuki, H., Nagai, K., Akutsu, E., Yamaki, H., Tanaka, N., Umezawa, H., 1970. On the mechanism of action of bleomycin: strand scission of DNA caused by bleomycin and its binding to DNA in vitro. J. Antibiot. 23, 473-480.

Tetlow, I.J., Farrar, J.F., 1993. Apoplastic sugar concentration and pH in barley leaves infected with brown rust. J. Exp. Bot. 45, 929-936.

Toscano-Underwood, C., West, J.S., Fitt, B.D.L., Todd, A.D., Jedryckzka, M., 2001 Development of phoma lesions on oilseed rape leaves inoculated with ascospores of A-group and B-group Leptosphaeria maculans (stem canker) at different temperatures and wetness durations. Plant. Pathol. 50, 28-41.

Trapnell, C., Williams, B.A., Pertea, G., Mortazavi, A., Kwan, G., van Baren, M.J. Salzberg, S.L., Wold, B.J., Pachter, L., 2010. Transcript assembly and quantification by RNA-Seq reveals unannotated transcripts and isoform switching during cell differentiation. Nat. Biotechnol. 28, 511-515.

Van de Wouw, A.P., Lowe, R.G.T., Elliott, C.E., Dubois, D.J., Howlett, B.J., 2014. An avirulence gene, AvrLmJ1, from the blackleg fungus, Leptosphaeria maculans, confers avirulence to Brassica juncea cultivars. Mol. Plant Pathol. 15, 523-530.

Van den Ackerveken, G.F.J.M., Dunn, R.M., Cozijnsen, A.J., Vossen, J.P.M.J., Van den Broek, H.W.J., De Wit, P.J.G.M., 1994. Nitrogen limitation induces expression of the avirulence gene avr9 in the tomato pathogen Cladosporium fulvum. Mol Gen. Genet. 243, 277-285.

van Dijk, K., Fouts, D.E., Rehm, A.H., Hill, A.R., Collmer, A., Alfano, J.R., 1999. The Avr (effector) proteins HrmA (HopPsyA) and AvrPto are secreted in culture from Pseudomonas syringae pathovars via the Hrp (Type III) protein secretion system in a temperature- and pH-sensitive manner. J. Bacteriol. 181, 4790-4797.

Wei, Z.M., Sneath, B.J., Beer, S.V., 1992. Expression of Erwinia amylovora genes in response to environmental stimuli. J. Bacteriol. 174, 1875-1882.

Whigham, E., Qi, S., Mistry, D., Surana, P., Xu, R., Fuerst, G., Pliego, C., Bindschedler, L. V., Spanu, P.D., Dickerson, J.A., Innes, R.W., Nettleton, D., Bogdanove, A.J., Wise R.P., 2015. Broadly conserved fungal effector BEC1019 suppresses host cell death and enhances pathogen virulence in powdery mildew of barley (Hordeum vulgare L.). Mol. Plant Microbe Interact. 28, 968-983.

Wilson, L.M., Idnurm, A., Howlett, B.J., 2002. Characterization of a gene (sp1) encoding a secreted protein from Leptosphaeria maculans, the blackleg pathogen of Brassica napus. Mol. Plant Pathol. 3, 487-493.

Xiao, Y., Lu, Y., Heu, S., Hutcheson, S.W., 1992. Organization and environmental regulation of the Pseudomonas syringae pv syringae $61 \mathrm{hrp}$ cluster. J. Bacteriol. $174,1734-1741$.

Yoshinari, T., Noda, Y., Yoda, K., Sezaki, H., Nagasawa, H., Sakuda, S., 2010. Inhibitory activity of blasticidin A, a strong aflatoxin production inhibitor, on protein synthesis of yeast: selective inhibition of aflatoxin production by protein synthesis inhibitors. J. Antibiot. 63, 309-314. 